\title{
The Constitution in the Supreme Court: Full Faith and the Bill of Rights, 1889-1910
}

\author{
David P. Currie†
}

In an earlier issue of this Review I explored the constitutional decisions of the Court respecting economic matters during Melville W. Fuller's tenure as Chief Justice. ${ }^{1}$ This article discusses that period's remaining constitutional cases, which fall into two principal categories: those interpreting the Bill of Rights and those applying the article IV command that one state give "full Faith and Credit" to certain acts of another. ${ }^{2}$

\section{The Bill of Rights}

\section{A. Domestic Cases}

The ringing declarations of the first eight amendments have figured so prominently in the decisions of the late twentieth century that it is surprising how small a part they played in the Court's early history. ${ }^{3}$ The number of cases involving the Bill of Rights did increase during the Fuller period, but it can scarcely be said that the Court took an aggressive view of its responsibilities under those clauses. ${ }^{4}$

Most of the cases can be quickly noted. After Counselman $v$. Hitchcock $k^{5}$ had sensibly held that the fifth amendment precluded compulsion to give incriminating evidence without a grant of immunity as broad as the privilege itself, ${ }^{6}$ Brown $v$. Walker ${ }^{7}$ predict-

$\dagger$ Harry N. Wyatt Professor of Law, University of Chicago. My thanks to Karla Kraus and Richard Levy for valuable research assistance, to Mitchell Daffner for taming the computer, and to the Jerome S. Weiss Faculty Research Fund for helping to make this study possible.

1 See D. Currie, The Constitution in the Supreme Court: The Protection of Economic Interests, 1889-1910, 52 U. CHI. L. REv. 324 (1985).

2 U.S. Const. art. IV, § 1.

- See David Currie, The Constitution in the Supreme Court: The First Hundred YeARS passim (1985).

4 See Roche, Civil Liberty in the Age of Enterprise, 31 U. CHI. L. REv. 103, 135 (1963) ("[T]he Constitution had no effective civil liberties content-in the contemporary sense . . . -throughout the period [1870-1920] under analysis.").

s 142 U.S. 547 (1892) (Blatchford, J.).

- Id. at 585-86. The Court also sensibly held that the amendment's purpose required 
ably allowed compulsion to testify after the witness had been protected from any prosecution related to the transaction in question. ${ }^{8}$ Bradfield $v$. Roberts ${ }^{\theta}$ upheld a federal grant to a hospital run by a religious order on the persuasive ground that the hospital's purpose was "purely" secular and that the establishment clause did not require discrimination against those who also practiced religion. ${ }^{10}$ Gibson v. United States ${ }^{11}$ and Scranton v. Wheeler ${ }^{12}$ established the questionable "navigational servitude" doctrine permitting the United States to cut off access to navigable waters without compensation. ${ }^{13}$ Over dissents by Holmes and Brown, Kepner $v$.

that it be read to protect witnesses before a grand jury as well as in court. Id. at 562-63. The opinion is marred by lengthy recitations of barely relevant state-court decisions after the unfortunate fashion of the day. Cf. Leisy v. Hardin, 135 U.S. 100 (1890) (containing similar recitations), discussed in $\mathrm{D}$. Currie, supra note 1 , at 359 .

7161 U.S. 591 (1896) (Brown, J.). Justices Shiras, Gray, White, and Field dissented.

${ }^{8}$ Id. at 610. But see Hale v. Henkel, 201 U.S. 43 (1906) (Brown, J.). In Hale, the Court invoked British authority to state that it was unnecessary that the federal statutory immunity embrace state prosecutions because the privilege itself forbade only compulsion to accuse oneself of crimes "arising within the same jurisdiction and under the same sovereignty." The Court unrealistically termed the danger of conviction in another jurisdiction "unsubstantial and remote." Id. at 68-69. In Brown, 161 U.S. at 606-08, the Court had apparently reached the same conclusion but did not consider it directly relevant since Congress had validly provided for immunity from both federal and state prosecution.

175 U.S. 291 (1899) (Peckham, J.).

${ }_{10}$ Id. at 298-99; see also Quick Bear v. Leupp, 210 U.S. 50, $81-82$ (1908) (Fuller, C.J.) (upholding a grant to sectarian Indian schools). The Court was on shakier ground in extending its holding that the free exercise clause did not protect the rights of Mormons to practice polygamy, Reynolds v. United States, 98 U.S. 145, 165-66 (1879), discussed in D. CURRIE, supra note 3 , ch. 13, to hold that members of the Mormon Church could be disenfranchised, Davis v. Beason, 133 U.S. 333, 346-47 (1890) (Field, J.), the Church's charter revoked, and its property confiscated because of its advocacy of the crime, Mormon Church v. United States, 136 U.S. 1, $44-48$ (1890) (Bradley, J., over the dissent of Fuller, C.J., Field, and Lamar, JJ.). These measures went so far beyond the suppression of actual polygamy as to interfere with the basic right to associate with others of the same religious belief. See Philip Kurland, Reilgion and the Law 25 (1962) (concluding that in Davis "the alleged crime was adherence to a religious belief"); Willard King, Medville Weston Fuller 14748 (1967) (calling Fuller's dissent in the Mormon Church case one of his "greatest glories" and noting that Congress later restored the confiscated property); Roche, supra note 4, at 133 (arguing that the "core" of Field's dissent in the Mormon Church case "was that Congress could do anything it liked with Mormon opinion, but it could not 'confiscate' Mormon property") (quoting 136 U.S. at 66).

1166 U.S. 269 (1897) (Fuller, C. J.).

12179 U.S. 141 (1900) (Harlan, J.).

${ }^{13}$ Gibson, 166 U.S. at 276; Wheeler, 179 U.S. at 164-65. The Court seemed to confuse the regulatory power conferred by the commerce clause with a federal property interest. $C f$. Illinois Central R.R. v. Illinois, 146 U.S. 387 (1892) (creating the public-trust doctrine to limit the protection afforded by the contract clause), discussed in $\mathrm{D}$. Currie, supra note 1 , at 331-34. Eldridge v. Trezevant, 160 U.S. 452 (1896), on which the Court in Gibson relied, had been based upon a specific Louisiana statute giving the state a proprietary servitude for flood-control purposes. Id. at 463-64. In Scranton, Justice Shiras, who had written Eldridge, dissented from the extension of its holding, pointing out that Gibson too had relied on state- 
United States ${ }^{14}$ concluded without much reasoning that the double jeopardy clause forbade the United States to appeal an acquittal.15 Two conclusory 1909 decisions, ${ }^{16}$ largely ignoring analogous precedents, ${ }^{17}$ allowed Congress to evade fifth and sixth amendment safeguards applicable to criminal cases by labeling penalties for wrongdoing as "civil." ${ }^{18}$ Weems $v$. United States, ${ }^{19}$ in a good battle over

court precedents recognizing a servitude under state law. Scranton, 179 U.S. at 181-82. But Gibson had also expressly said that riparian titles in general were held "subject to the servitude in respect of navigation created in favor of the Federal government by the Constitution." Gibson, 166 U.S. at 272; see also United States v. Lynah, 188 U.S. 445, 471-74 (1903) (Brewer, J.) (despite the servitude, the government must pay for flooding caused by its navigation improvements); Bedford v. United States, 192 U.S. 217, 225 (1904) (McKenna, J.) (government need not pay when flooding resulted indirectly from improvements that interfered with natural erosion process); Clark v. Nash, 198 U.S. 361, 369-70 (1905) (Peckham, J.) (holding that a taking to irrigate a single plot of private land met the implicit "public use" requirement); cf. Chicago, B. \& Q.R.R. v. Chicago, 166 U.S. 226, 247-52 (1897) (Harlan, J.) (allowing nominal compensation for building a road across railroad property because there was minimal interference with existing uses, over a sensible Brewer dissent arguing that the proper measure was the market value of the easement).

14195 U.S. 100 (1904) (Day, J.). The case arose under a statute prohibiting double jeopardy in the Philippines. The Court reasonably concluded that the statute imposed the same standards as the fifth amendment itself. Id. at 121-24.

${ }^{18}$ Id. at 125-32; see also Grafton v. United States, 206 U.S. 333, 354-55 (1907) (soldier acquitted by military tribunal cannot be retried in Philippine civil court); In re Nielsen, 131 U.S. 176, 190 (1889) (Bradley, J.) (relying on authority and logic to hold that conviction barred trial for lesser included offense). But cf. Taylor v. United States, 207 U.S. 120, 127 (1907) (Holmes, J.) (government may appeal dismissal of indictment because, as explained in Kepner, jeopardy had not yet attached); Trono v. United States, 199 U.S. 521, 533-34 (1905) (Peckham, J.) (another Philippine case, holding on the fictitious basis of waiver that a defendant who appealed his conviction of one offense subjected himself to review of his acquittal of another).

16 Oceanic Steam Navigation Co. v. Stranahan, 214 U.S. 320, 336-38 (1909) (White, J.) (sustaining administrative penalty without judicial trial), and Hepner v. United States, 213 U.S. 103, 114-15 (1909) (Harlan, J.) (upholding directed verdict for United States despite defendant's right to trial by jury).

17 See Boyd v. United States, 116 U.S. 616, 633-35 (1886) (civil forfeiture proceeding within fifth amendment bar on self-incrimination); Ex parte Garland, 71 U.S. (4 Wall.) 333, 376-78 (1867) (finding civil disabilities punishment for purposes of the ex post facto and bill of attainder clauses); Cummings v. Missouri, 71 U.S. (4 Wall.) 277 (1867) (same); see also D. CurRIE, supra note 3, chs. 9, 13. In Hepner, 213 U.S. at 112, Harlan read Boyd as confirming that civil penalty proceedings were constitutional.

18 But cf. Wong Wing v. United States, 163 U.S. 228, 237 (1896) (Shiras, J.) (holding that an alien could not be put to hard labor without an indictment and jury trial). Other jury-trial decisions of the Fuller period include Capital Traction Co. v. Hof, 174 U.S. 1, 3739 (1899) (Gray, J.) (seventh amendment forbids one civil jury to review another, but a "jury" in a trial conducted by a justice of the peace is not a "jury" for seventh amendment purposes); Thompson v. Utah, 170 U.S. 343, 349 (1898) (Harlan, J.) (sixth amendment preserves traditional requirement that criminal jury consist of twelve persons); American Publishing Co. v. Fisher, 166 U.S. 464, 467-68 (1897) (Brewer, J.) (seventh amendment preserves traditional requirement that civil jury decide unanimously).

10217 U.S. 349 (1910) (McKenna, J.). Justices White and Holmes dissented, and three Justices did not participate. 
the relevant history, concluded that the eighth amendment's ban on cruel and unusual punishments forbade a sentence disproportionate to the offense.

Two freedom of expression cases deserve somewhat closer attention. Study of this area tends to begin with the great espionage cases of the First World War, ${ }^{20}$ but earlier decisions had exhibited an even more grudging attitude towards the first amendment. ${ }^{21}$ The Waite Court had mingled notions of immorality with those of proprietary rights in allowing exclusion of lottery materials from the mails ${ }^{22}$ and had upheld restrictions on the political activities of federal employees without even discussing the first amendment. ${ }^{23}$ The Fuller Court was almost as cavalier.

In 1904, in United States ex rel. Turner $v$. Williams, ${ }^{24}$ the Court allowed Congress to exclude an alien from the country on the ground that he was an anarchist. After suggesting that the law was not a limitation on speech at all and that the first amendment did not apply to aliens seeking entry, ${ }^{25}$ Chief Justice Fuller de-

${ }^{20}$ E.g., Schenck v. United States, 249 U.S. 47 (1919).

${ }^{21}$ See generally Rabban, The First Amendment in Its Forgotten Years, 90 YaLE L.J. 514,557 (1981) (concluding, after a review of both federal and state decisions, that "[a] general hostility to the value of free expression permeated the judicial system" before the war).

22 See Ex parte Jackson, 96 U.S. 727 (1878), discussed in D. CurRIE, supra note 3, ch. 13. This holding was reaffirmed in In re Rapier, 143 U.S. 110, 134 (1892) (Fuller, C.J.), on the basis of a distinction made much later in the context of abortion: "The circulation of newspapers is not prohibited, but the government declines itself to become an agent in the circulation of printed matter which it regards as injurious to the people." Compare Roe v. Wade, 410 U.S. 113 (1973) (state cannot criminally prohibit abortion in first trimester), with Maher v. Roe, 432 U.S. 464 (1977) (state not required to fund constitutionally protected abortions), and Harris v. McRae, 448 U.S. 297 (1980) (federal government not required to fund constitutionally protected abortions).

${ }^{23}$ See Ex parte Curtis, 106 U.S. 371 (1882), discussed in D. CurrIE, supra note 3, ch. 13. Only Justice Bradley, in dissent, considered the first amendment. Curtis, 106 U.S. at 376-78.

24194 U.S. 279 (1904) (Fuller, C.J.).

${ }^{25}$ Id. at 292. The Court stated: "It is . . . true that . . . he is in fact cut off from . . . speaking or publishing . . . in the country, but that is merely because of his exclusion therefrom. He does not become one of the people to whom these things are secured by our Constitution by an attempt to enter forbidden by law." In an earlier decision, Davis v. Massachusetts, 167 U.S. 43, 47-48 (1897) (White, J.), the Court had not even mentioned freedom of expression in upholding a prohibition on speaking in a public park without a permit by reasoning that the right to exclude everyone from public property "necessarily include[d]" the "lesser" authority to limit use. The Court quoted from then Justice Holmes's decision in the court below: "For the legislature absolutely or conditionally to forbid public speaking in a highway or public park is no more an infringement of the rights of a member of the public than for the owner of a private house to forbid it in his house." Id. at 47 (quoting from Commonwealth v. Davis, 162 Mass. 510, 511, 39 N.E. 113, 113 (1895) (Holmes, J.)); cf. Western Union Tel. Co. v. Kansas, 216 U.S. 1 (1910), discussed in D. Currie, supra note 1, at 377 
clared that it required no argument to show that a person who "believes in or advocates the overthrow of the Government . . . by force" could be denied admission. ${ }^{26}$ Moreover, if the word "anarchist" included mere "political philosophers innocent of evil intent," it was enough, "in the light of previous decisions" not identified, that Congress had thought "the tendency of the general exploitation of such views . . . so dangerous" as to justify exclusion: "as long as human governments endure they cannot be denied the power of self-preservation . . . ."27 No effort was made to reconcile these conclusions with the text, history, or purpose of the first amendment or to explain why, assuming the test was whether a measure impinging on expression was necessary for "self-preservation," it was consistent with Marbury v. Madison ${ }^{28}$ to let Congress be the sole judge of necessity. ${ }^{20}$

The second case was Patterson $v$. Colorado, ${ }^{30}$ where Justice Holmes wrote to sustain a contempt citation for publications that "reflected upon the motives and conduct of the Supreme Court of Colorado in cases still pending." 31 Echoing Turner's concern for countervailing governmental interests without citing that decision, Holmes invoked state-court and English decisions recognizing a sufficient interest in "preventing interference with the course of justice." ${ }^{32}$ Like Fuller in Turner, Holmes seemed extremely deferential to someone else's findings regarding the necessity for limiting expression: "if a court regards, as it may, a publication concerning a matter of law pending before it, as tending toward such an interference, it may punish it . . . ."33

n.315. In Western Union, Holmes dissented from the Court's arguably distinguishable holding that a state could not condition the privilege of doing local business on payment of taxes on out-of-state property. 216 U.S. at 52.

28 Turner, 194 U.S. at 293.

${ }_{27}$ Id. at 294. Justice Brewer, concurring, more modestly said the evidence established that Turner "urges and seeks the overthrow by force of all government" and thus it was unnecessary to consider whether Congress could exclude "one who simply entertains and expresses the opinion that all government is a mistake, and that society would be better off without any." Id. at 296.

28 5 U.S. (1 Cranch) 137 (1803).

${ }^{29}$ Cf. McCulloch v. Maryland, 17 U.S. (4 Wheat.) 316, 386-87 (1819) (refusing to reexamine the degree of necessity of a federal statute for purposes of the necessary and proper clause), discussed in D. Currie, supra note 3, ch. 6. See also Ernst Freund, The Police PowER $\S 478$ (1904) (arguing that the immigration statute was valid because it did not "restrain the freedom of speech of anarchists residing in the country").

so 205 U.S. 454 (1907).

31 Id. at $458-59$.

32 Id. at 463.

ss $I d$. 
Indeed, Holmes began his discussion of the first amendment by announcing a far more restrictive principle that seemed to make his investigation of the state's interest unnecessary: "the main purpose of such constitutional provisions is 'to prevent all such previous restraints upon publications as had been practiced by other governments,' and they do not prevent the subsequent punishment of such as may be deemed contrary to the public welfare." ${ }^{34}$ Cited for this momentous proposition, without elaboration, were two decisions construing state constitutions and Blackstone's view of the English common law. ${ }^{36}$ Whether the fourteenth amendment made the first applicable to the states at all he expressly left open. ${ }^{36}$

The opinion demonstrated the advantages and disadvantages of Holmes's characteristic brevity: Holmes neither wasted the reader's time nor justified his important and debatable conclusions.

${ }^{34}$ Id. at 462 (quoting Commonwealth v. Blanding, 20 Mass. (3 Pick.) 304, 313 (1826)) (emphasis in original).

${ }^{3 s}$ Blanding, 20 Mass. at 313; Respublica v. Oswald, 1 Dall. 319, 325 (Pa. 1798). Story had suggested in his treatise that the Constitution preserved the English distinction between prior restraint and subsequent punishment. 3 Joseph STORY, Commentaries on THE Constitution of the United States $\$ 1878$ (1833). Cooley disagreed. Thomas Cooley, ConSTitutional Limitations, ch. 12 (3d ed. 1874). Harlan also disagreed, assuming his conclusion by declaring that "[ $t]$ he public welfare cannot override constitutional privileges." Patterson, 205 U.S. at 465 (Harlan, J., dissenting). For the argument that the amendment was meant to confirm the original Constitution's total exclusion of the federal government from the area of speech and press, see Mayton, Seditious Libel and the Lost Guarantee of a Freedom of Expression, 84 CoLuM. L. REv. 91 (1984). Story recognized but did not comment on this possibility. $3 \mathrm{~J}$. STORY, supra $\S 1885$.

${ }^{36} 205$ U.S. at 462 . Justice Harlan, who had previously argued that the fourteenth amendment incorporated other provisions of the Bill of Rights, see, e.g., O'Neil v. Vermont, 144 U.S. 323, 370 (1892) (dissenting opinion); Hurtado v. California, 110 U.S. 516, 538-58 (1884) (dissenting opinion), concluded in dissent that free expression was an "attribute[] of natural citizenship" protected by the privileges or immunities clause against state action and an "essential part[] of every man's liberty" protected by the due process clause as well. Patterson, 205 U.S. at 464-65.

During the Fuller years the majority held that the fourteenth amendment did not make applicable to the states the eighth amendment ban on cruel and unusual punishments, In re Kemmler, 136 U.S. 436, 448-49 (1890) (Fuller, C.J.), the sixth amendment right to a twelvemember criminal jury, Maxwell v. Dow, 176 U.S. 581, 604-05 (1900) (Peckham, J.), or the fifth amendment privilege against self-incrimination, Twining v. New Jersey, 211 U.S. 78, 113-114 (1908) (Moody, J.). Justice Harlan dissented in both Maxwell, 176 U.S. at 605, and Twining, 211 U.S. at 114. He was able to write for the Court, however, in feigned reliance on a case that had flatly stated the contrary, that the fourteenth amendment did forbid a state to take property without just compensation. See Chicago, B. \& Q.R.R. v. Chicago, 166 U.S. 226, 235-41 (1897) (citing Davidson v. New Orleans, 96 U.S. 97 (1878)), discussed supra note 13; see also Missouri Pac. R.R. v. Nebraska, 164 U.S. 403, 417 (1896) (Gray, J.) (holding the due process clause forbade a state to order a railroad to permit the. construction of a private grain elevator on its land). See generally D. CurRIE, supra note 3, chs. 10, 11 (discussing earlier fourteenth amendment decisions). 


\section{B. The Insular Cases}

The most interesting and controversial decisions about the Bill of Rights during the Fuller era, however, are found among a series of cases concerning the applicability of various constitutional provisions to the islands acquired from Spain as a result of the Spanish-American war. ${ }^{37}$

The story begins with three 1901 decisions regarding tariffs for goods shipped to or from what was then called Porto Rico. In the course of holding that the island was no longer a "foreign" country within the meaning of the tariff law, De Lima v. Bidwell ${ }^{38}$ reaffirmed that territory could constitutionally be acquired by treaty ${ }^{38}$ - a proposition sanctioned by long practice and unchal-

37 See generally 2 Chardiss Warren, The Supreme Court in United States History 708 (rev. ed. 1937) (describing these cases as "the most important fact in the Court's history" during the Fuller and White periods); W. KING, supra note 10, at 262-77.

38 182 U.S. 1 (1901) (Brown, J.). Justices McKenna, Shiras, White, and Gray dissented.

The same term, in Dooley v. United States, 183 U.S. 151 (1901) (Brown, J.), the Court relied on De Lima and on Woodruff v. Parham, 75 U.S. (8 Wall.) 123 (1869), discussed in D. CURrie, supra note 3 , ch. 10 , to hold that a tax on goods sent from the United States mainland to Porto Rico was not a tax on "Exports" forbidden by article I, section 9. Four dissenters-Fuller, Harlan, Brewer, and Peckham-stressed the fact that Woodruff, which had given a narrow reading to the related clause of article $I$, section 10 , forbidding state taxes on "Imports," had dealt with shipments from one state to another rather than to an overseas possession. Dooley, 183 U.S. at 170-72; see also Whitney, The Insular Decisions of December, 1901, 2 Colum. L. Rev. 79 (1902) (criticizing the decision).

30 De Lima, 182 U.S. at 195-96 (quoting American Ins. Co. v. Canter, 26 U.S. (1 Pet.) 511,542 (1828) (dictum), discussed in D. CurRIE, supra note 3, ch. 4). In Geofroy v. Riggs, 133 U.S. 258 (1890) (Field, J.), the Court had sensibly interpreted the treaty power to include "any matter which is properly the subject of negotiation with a foreign country." Id. at 267. That the subject in question was the right of an alien to inherit land in the United States suggests the breadth of the authority thus recognized. The court's expansive language is limited somewhat by the facts of the case; because the land at issue was located in the District of Columbia, the Court did not hold that the treaty power extended to subjects over which Congress could not legislate. Four years later, in Wharton v. Wise, 153 U.S. 155 (1894) (Field, J.), the Court suggested a narrow interpretation of what constituted a treaty under the Constitution by holding that an interstate compact respecting fishing rights was not contrary to the provision of the Articles of Confederation forbidding the states to enter into any "treaty, confederation, or alliance" without congressional consent. Justice Field stated:

The articles . . . were intended to prevent any union of two or more States, having a tendency to break up or weaken the league between the whole; they were not designed to prevent arrangements between adjoining States to facilitate the free intercourse of their citizens, or remove barriers to their peace and prosperity . . . .

Id. at 167. The result in Wharton was echoed in United States v. Belmont, 301 U.S. 324 (1937). There the Court, lent support by the explicit distinction between state "treaties" and "compacts" in the present article I, section 10, held that not every federal agreement with a foreign country required Senate approval under the treaty clause of article II, section 2. Belmont, 301 U.S. at $330-31$. More debatable was the decision in Virginia v. Tennessee, 148 U.S. 503 (1893) (Field, J.), that even the compact clause did not require congressional 
lenged in the instant case. Dooley $v$. United States ${ }^{40}$ followed longstanding precedent ${ }^{41}$ in upholding the power of the occupying authorities to impose tariffs on incoming goods as an incident of military government. ${ }^{42}$ Downes $v$. Bidwell ${ }^{43}$ was another matter; notwithstanding the contemporaneous decision that Porto Rico was not "foreign," the Court held, over dissents by Fuller, Harlan, Brewer, and Peckham, that the island could be discriminatorily taxed despite the constitutional requirement that duties be "uniform throughout the United States."45

Speaking for himself alone, Justice Brown wrote a distressing opinion in which he came close to arguing that nothing in the Constitution applied to any of the territories. ${ }^{46}$ As the other eight Justices insisted, the contrary had long been established, ${ }^{47}$ and

consent for every agreement between states, but only for those "tending to the increase of political power in the States, which may encroach upon or interfere with the just supremacy of the United States." Id. at 519. Since this was practically the same definition that the Court would later announce in regard to treaties in Wharton, it was just as well that Field added Story's explanation that treaties dealt with "political" matters and compacts with "mere private rights of sovereignty" such as boundaries. Id. (quoting $3 \mathrm{~J}$. STORY, supra note 35 , at $\$ 1403$ ).

10182 U.S. 222 (1901) (Brown, J.).

12 E.g., Cross v. Harrison, 57 U.S. (16 How.) 164 (1854), cited in Dooley, 182 U.S. at 231-33.

12 The majority held that military authority to tax imports from the United States ended when the territory was ceded to this country. Dooley, 182 U.S. at 233-34. The Justices who had dissented in De Lima on the ground that Porto Rico remained a "foreign country" also dissented from this conclusion. Id. at 237-38 (White, Gray, Shiras and McKenna, JJ., dissenting).

13182 U.S. 244 (1901).

14 See De Lima, 182 U.S. at 200. For an early argument that Downes was inconsistent with De Lima-only Justice Brown sided with the majority in both decisions-see Burgess, The Decisions of the Supreme Court in the Insular Cases, 16 PoL. Scr. Q. 486, 494-99 (1901).

15 U.S. CoNST. art. I, § 8. The duty was on goods imported to the mainland from Porto Rico. There was no comparable duty on shipments from one state to another, and some Justices contended that imposition of such a duty would be unconstitutional, Downes, 182 U.S. at 292 (White, J., concurring), though the Court had struck down state taxes on such shipments on the ground that federal power over interstate commerce was exclusive, see, e.g., Case of the State Freight Tax, 82 U.S. (15 Wall.) 232 (1873), discussed in D. CurRIE, supra note 3 , ch. 10.

18 See Downes, 182 U.S. at 285-86; see also Rassmussen v. United States, 197 U.S. 516, 531-32 (1905) (Brown, J., concurring). Elsewhere in Downes, however, he suggested that the ex post facto and bill of attainder clauses did apply, as well as "certain principles of natural justice . . . which need no expression in constitutions." 182 U.S. at 276-77, 280, 282-83.

${ }^{7}$ See Downes, 182 U.S. at 291-92 (White, J., concurring); id. at 360-63 (Fuller, C.J., dissenting) (citing, inter alia, Scott v. Sandford, 60 U.S. (19 How.) 393 (1857) (power of Congress to legislate regarding territories limited by the Constitution), and Thompson v. Utah, 170 U.S. 343 (1898) (same)). In Downes, Brown argued that most of the precedents were distinguishable because Congress had extended the Constitution to the territories in those cases by statute. 182 U.S. at 258, 269-70. But, as the other Justices pointed out, the 
Brown's theory left one wondering how a nation with only the powers given in the Constitution could govern territories at all. ${ }^{48}$ The real question, as Justice White argued in an impressive opinion basically joined by the remaining three members of the majority, was whether Porto Rico was a part of "the United States" within the meaning of the uniformity clause. ${ }^{49}$

Brown concluded that no territory was a part of the United States, essentially because, as had been established in Marshall's time, no territory was a state. ${ }^{50}$ The "United States," he argued with some plausibility as an original matter, meant the states themselves; an early draft of the Constitution had placed the uniformity clause among other provisions explicitly protecting states from discrimination. ${ }^{51}$ Fuller came up with troubling counteranalogies in dissent, ${ }^{\mathbf{6} 2}$ but the great difficulty for Brown was precedent.

Court had not always relied on those statutes, and Brown's theory failed to explain why Congress had the power to enact them.

48 See D. Currie, supra note 3, chs. 4, 8 (discussing American Ins. Co. v. Canter, 26 U.S. (1 Pet.) 511 (1828), and Scott v. Sandford, 60 U.S. (19 How.) 393 (1857)).

49 Downes, 182 U.S. at 287-88, 299 (White, J., joined by Shiras and McKenna, JJ., concurring). Justice Gray agreed "in substance" with White's opinion. Id. at 345 (Gray, J., concurring). That the island was no longer "foreign," as held in De Lima, was not conclusive. As a textual matter it is entirely conceivable for an American possession to be independent of the influence of other nations without being a part of the United States. Cf. Cherokee Nation v. Georgia, 30 U.S. (5 Pet.) 1 (1831) (holding an Indian tribe not a "foreign State" within article III despite a history of separate existence and self-government emphasized by the negotiation of treaties with the United States), discussed in D. CuRRIE, supra note 3, ch. 4 .

so Downes, 182 U.S. at $250-51,259,277,278$. Brown cited, inter alia, New Orleans v. Winter, 14 U.S. (1 Wheat.) 91 (1816), and Hepburn v. Ellzey, 6 U.S. (2 Cranch) 445 (1805), discussed in D. CurRIE, supra note 3, ch. 3. Winter and Hepburn respectively had held that citizens of neither the territories nor the District of Columbia were citizens of a "State" for purposes of diversity jurisdiction.

s1 Justice Brown also pointed to the fact that the thirteenth amendment distinguished between "the United States" and "places within [its] jurisdiction." Downes, 182 U.S. at 251. But this proved at most that some places subject to American authority were outside the United States, not that Porto Rico was. Cf. Neely v. Henkel, 180 U.S. 109, 122-23 (1901) (holding that despite American military occupation Cuba remained a foreign country), discussed in Downes, by White, 182 U.S. at 343-44, and Harlan, id. at 387-88 (Harlan, J., dissenting). Fuller went further, describing the amendment's "jurisdiction" clause as having been inserted "out of abundant caution." 182 U.S. at 358 (Fuller, C.J., dissenting). For an earlier argument in support of Brown's position, see Langdell, The Status of Our New Territories, 12 HaRv. L. REv. 365, 379-91 (1899).

${ }^{52}$ Fuller cited Justice Miller's statement in the Slaughter-House Cases, 83 U.S. (16 Wall.) 36, 74 (1873), that one could be a "citizen of the United States" within the fourteenth amendment without being a citizen of a state. Downes, 182 U.S. at 357 (Fuller, C.J., dissenting). Fuller also asserted that it was not clear that the framers would have wanted to disqualify a territorial resident from the Presidency under article II's requirement of 14-year residence "in the United States." Id.; cf. U.S. ConST. art. III, \$1 ("The judicial Power of the United States . . . ."). For a strong anticipatory reply to Brown's position on this question, 
In upholding Congress's power to impose taxes in the District of Columbia, Chief Justice Marshall had said that the power to tax extended as far as the uniformity clause that limited its exercise, and that the District of Columbia was part of "the United States."33 Brown responded that the District was different from the territories because it had been formed out of portions of Maryland and Virginia. ${ }^{54}$ Whether or not this satisfied his own definition of "the United States," shall's conclusion; Marshall had flatly said that the clause's purpose of preventing discrimination was applicable to the entire "American empire," expressly including the territories. ${ }^{56}$

To Chief Justice Fuller and his brethren in dissent, Marshall's decision meant that Porto Rico was part of "the United States." Justice White, for the remaining four Justices, took an imaginative intermediate view: a territory became part of the United States only after it had been "incorporated" by congressional action. ${ }^{.8}$ Justice Harlan protested that this would leave it to Congress to determine whether or not to abide by constitutional limitations, ${ }^{59}$ but the tenor of White's opinion suggested he was speaking, as he should have been, only of provisions limited in their application to "the United States." dence that it is not unusual for a country to have possessions that are not considered part of the country itself, and White catalogued

see Lowell, The Status of Our New Possessions-A Third View, 13 Harv. L. Rev. 155, 15763 (1899).

${ }^{53}$ Loughborough v. Blake, 18 U.S. (5 Wheat.) 317 (1820), discussed in D. CuRRIE, supra note 3 , ch. 6 .

st Downes, 182 U.S. at 260-61.

ss Brown elsewhere insisted that "the United States" meant the states themselves. See supra note 51 and accompanying text. The District was no longer part of a state, see Hepburn v. Ellzey, 6 U.S. (2 Cranch) 445 (1805), though an occasional speaker during the ratification debates had argued that it would be, see 3 Jonathan Ellot, Debates in THE Several State Conventions on the Adoption of the Federal Constitution 434-35 (2d ed. 1836) (Mr. Nicholas speaking). But see id. at 435 (Mr. Grayson) (arguing the opposite).

${ }^{86}$ Loughborough, 18 U.S. (5 Wheat.) at 317.

${ }^{87}$ Downes, 182 U.S. at 352-56 (Fuller, C.J., dissenting).

${ }^{58}$ Id. at 287-344 (White, J., joined by Shiras and McKenna, JJ., concurring). Justice Gray wrote separately to say he agreed "in substance" with White's opinion. Id. at 344-45 (Gray, J., concurring). The incorporation thesis had first been suggested by Lowell, supra note 52 , at 176.

s8 182 U.S. at 389 (Harlan, J., dissenting).

${ }^{60}$ See, e.g., id. at 292, 299, 341-42 (White, J., concurring). Significantly, White's conclusion appeared applicable to the troublesome question of citizenship, which under the fourteenth amendment extended to most persons born "in the United States." See id. at 306, 313. For a sample of the fears conjured up on this score, see Stevenson, The Relation of the Nation to its Dependencies, 36 AM. L. REv. 366, 383-86 (1902). 
ample reasons why a country might do so. ${ }^{61}$ Not only was there no evidence that the framers of the uniformity clause had meant to rule out this traditional distinction, but White impressively mustered history suggesting that early American practice had distinguished between mere acquisition and incorporation. ${ }^{62}$ On the subordinate question whether Porto Rico had been incorporated, White was less powerful; ${ }^{63}$ but he did seem on respectable ground in concluding that not everything over which the federal government exercised sovereignty was necessarily a part of "the United States." ${ }^{64}$

Three years later, with only Harlan dissenting, the Court held in Dorr v. United States ${ }^{65}$ that the constitutional provisions requiring juries in criminal trials ${ }^{66}$ did not apply to the Philippines. Downes had settled, Justice Day began, that unincorporated territories were to be governed by Congress "subject to such constitutional restrictions . . . as are applicable to the situation." "67 On its face this statement applied equally to incorporated territories, since by definition everything Congress does is subject to "applicable" constitutional limitations. ${ }^{68}$ Day's emphasis on the fact that the Philippines had not been incorporated, ${ }^{69}$ however, suggests

1 Downes, 182 U.S. at 306-13 (White, J., concurring).

${ }^{62}$ Id. at 322-39 (quoting, inter alia, correspondence to show that then President Jefferson had never doubted the power to acquire Louisiana by treaty, but only the authority to make it part of the United States). Fuller hardly replied to White's argument. See id. at 371-73 (Fuller, C.J., dissenting). Harlan, in a separate dissent, fulminated ineffectually against "monarchical" or "arbitrary" government and professed to find White's distinction incomprehensible. Id. at 380-81, 391. For a contemporaneous argument that history did not support White's distinction, see Randolph, The Insular Cases, I Colum. L. REv. 436, 451 (1901).

63 White said essentially only that the treaty itself had not done the trick, Downes, 182 U.S. at 339-40 (White, J., concurring); he hardly responded to Harlan's argument, id. at 39091 (Harlan, J., dissenting), that Congress had "incorporated" the territory by enacting a variety of provisions creating, among other things, a permanent civil government. See also Randolph, supra note 62 , at $454-57$.

ot The language of Loughborough v. Blake, 18 U.S. (5 Wheat.) 317 (1820) (discussed supra note 53 and accompanying text), was broad enough to cover all American possessions, but the Court there had not addressed the question of incorporation of outlying possessions. See also Downes, 182 U.S. at 387-88 (Harlan, J., dissenting) (distinguishing Neely v. Henkel, 180 U.S. 109 (1901), on the grounds that there the United States had exercised military control of conquered Cuban territory but had made no claim of sovereignty).

os 195 U.S. 138 (1904).

so U.S. ConsT. art. III, § 2, cl. 3; id. amend. VI.

${ }^{67}$ Dorr, 195 U.S. at 143.

68 Day finally settled an ancient controversy by flatly declaring that it was the provision of article IV, \& 3, cl. 2 for "Regulations" respecting "the Territory" that gave Congress authority to govern the territories in the first place. Id, at 146, 149; see D. CurrIE, supra note 3, ch. 8 (discussing Scott v. Sandford, 60 U.S. (19 How.) 393 (1857)).

62195 U.S. at 143-44. 
that he took Downes as having established White's distinction between incorporated and unincorporated areas, although White had not spoken for a majority of participating Justices. ${ }^{70}$ Indeed it was only by embracing White's distinction that Day could avoid an earlier decision, which he ignored, that had found it "beyond question" that the jury provisions were applicable in Utah before statehood.71

Day was quite right to concede that Downes had not held all constitutional limitations inapplicable to unincorporated territories. As White had stressed in his concurring opinion in Downes, ${ }^{72}$ all that that case had purported to settle was that such territories were not subject to a provision limited in terms to "the United States," and the jury provision of article III contained no such limitation..$^{73}$ In the intervening case of Hawaii v. Mankichi, ${ }^{74}$ however, White had written a concurring opinion concluding, without any reference to the compelling distinction he had previously drawn, that Downes "controlled" the jury question as well. ${ }^{25}$

${ }^{70}$ It was fair enough to conclude that a majority in Downes had held at least unincorporated territories not within "the United States," since Justice Brown had said the same of all territories. See supra notes 50-51 and accompanying text.

71 Thompson v. Utah, 170 U.S. 343, 347 (1898), cited in Dorr, 195 U.S. at 155 (Harlan, J., dissenting); see also Rassmussen v. United States, 197 U.S. 516, 525-26 (1905) (White, J.) (reaffirming the incorporation thesis in finding the criminal jury requirements violated in Alaska); Binns v. United States, 194 U.S. 486, 490-91 (1904) (Brewer, J.) (holding the uniformity requirement applicable to Alaska because that territory had been incorporated, but holding that the requirement had not been infringed).

${ }^{72}$ See, e.g., 182 U.S. at 292 ("[T] tion is operative, . . . but whether the provision relied on is applicable."); supra note 49 and accompanying text.

${ }^{73}$ U.S. ConsT. art. III, § 2, cl. 3 ("The trial of all Crimes . . . shall be by Jury . . . ."). The sixth amendment does speak in its venue provisions only of states, but in light of the accepted impetus for the Bill of Rights it would be perverse to conclude it was meant to diminish the protection afforded by the original Constitution.

74 190 U.S. 197 (1903) (Brown, J.).

${ }^{75} I d$. at 219. In Dorr, three of the Justices who had dissented in both Downes and Mankichi thought the latter case had settled the jury question, Dorr, 195 U.S. at 153-54 (Peckham, Brewer, JJ., and Fuller, C.J., concurring), but Day did not treat Mankichi as decisive, correctly noting that White's statement was part of a concurring opinion. Id. at 144 (majority opinion). Indeed, the majority in Mankichi had oddly contrived not to discuss the constitutional question. After holding that a joint resolution preserving local laws not "contrary to the Constitution" extended only "fundamental" constitutional provisions to the islands, 190 U.S. at 217-18, Justice Brown in Mankichi concluded it was unnecessary "to reconsider the questions which arose in the Insular Tariff cases regarding the power of Congress to annex territory without at the same time extending the Constitution over it." Id. at 218. If the Constitution itself required a jury, of course, it was immaterial whether the resoIution also did; the explanation for Day's refusal to discuss the constitutional question seems to be that the case was "argued upon th[e] theory" that the congressional resolution was determinative. Id. If the further suggestion that the Court believed the resolution deci- 
Justice White gave no reason in Mankichi for concluding that the jury provision applied only in "the United States" beyond an unexplained reference to In re Ross, ${ }^{76}$ which had suggestively but not decisively held that no jury was required in a consular court in a foreign country. ${ }^{77}$ In Dorr, Day essentially said only that the framers could not have meant to frustrate justice by requiring juries in "a territory peopled by savages." this conclusion, as he could have, by citing either Ross or Ex parte Milligan's ${ }^{79}$ dictum that military necessity would have justified dispensing with juries in rebel areas during the Civil War. Even if Day was right that the uncompromising text of the Constitution did not really require the impossible, moreover, Milligan itself required some showing that jury trials were out of the question in the Philippines before holding the guarantee inapplicable, ${ }^{80}$ and Day did not make it. Thus the important question of the geographical scope of the criminal jury was decided essentially without explanation; and the dissenters never managed to show why in Jus-

sive, id., meant that the Justices thought Downes had settled the inapplicability of the constitutional jury provisions, the Court had some explaining to do, for reasons given in the text. See text accompanying notes $72-81$.

On the nonconstitutional issue, the majority in Mankichi was not persuasive; the resolution did not say that only "fundamental" provisions were extended to the islands, and, as counsel argued, all constitutional requirements were "equally imperative whatever view the court may take of the[ir] relative importance." 190 U.S. at 206. Once again Justice White had a better theory: the resolution merely made clear that nothing in its terms should be read to preserve any laws inconsistent with those "fundamental" constitutional provisions "which were by their own force applicable to the territory with which Congress was dealing." Id. at 220-21 (White, J., concurring); cf. D. CURRIE, supra note 3, ch. 10 (discussing the controversy over whether the fourteenth amendment provision forbidding states to abridge "the privileges or immunities of citizens of the United States" made provisions previously limiting only the United States binding on the states as well).

76140 U.S. 453 (1891) (Field, J.).

77 There is language in Ross to support both its extension to unincorporated territories and its limitation to foreign countries. Cf. supra note 49 (discussing critically the distinction drawn in Downes and De Lima between American possessions and foreign countries).

Additional cases cited by White in Mankichi, 190 U.S. at 220 (White, J., concurring), holding the Bill of Rights inapplicable to state action, e.g., Hurtado v. California, 110 U.S. 516 (1884), were even less clearly relevant, since White did not seem to deny that the action complained of in Mankichi was that of agents of the federal government. An argument might have been made that the indigenous authorities, like Indian tribes, were not in fact exercising federal authority, cf. Talton v. Mayes, 163 U.S. 376, 382-84 (1896) (White, J.) (grand jury requirement inapplicable to Cherokee Nation because no exercise of federal authority involved), but White did not develop this argument either.

${ }^{78}$ Dorr, 195 U.S. at 148 . He added with less force that he also did not believe they had meant to require juries where contrary to local customs. Id.

7971 U.S. (4 Wall.) 2, 124-27 (1866), discussed in D. Currie, supra note 3, ch. 9.

so 71 U.S. (4 Wall) at 127 (martial law justifiable only if there is a real threat, "such as effectually closes the courts and deposes the civil administration"). 
tice White's own terms the jury question was different from the uniformity issue decided in Downes. ${ }^{81}$

\section{Full Faith and Credit}

Article IV's requirement that "Full Faith and Credit shall be given in each State to the public Acts, Records, and judicial Proceedings of every other State"82 had not figured prominently in Supreme Court decisions of the first hundred years. Two important principles respecting this clause and its implementing statute, ${ }^{83}$ however, had been established without much discussion. In general, a judgment was to be given the same effect everywhere that it had in the state that had rendered it, ${ }^{84}$ but the judgment of a court lacking jurisdiction according to traditional rules of private international law was entitled to no respect. ${ }^{85}$ The Court under Fuller took several opportunities to elaborate these principles.

\section{A. Huntington v. Attrill}

Huntington sued in Maryland to enforce a New York judgment obtained under a statute making directors who had made false statements liable for corporate debts. The Maryland court found the judgment "penal" 'and refused to enforce it. The Supreme Court, in an 1892 Gray opinion, reversed: it was true that penal judgments fell outside the full faith and credit clause, but this judgment was not penal. ${ }^{86}$

For the first proposition, Gray relied on his own recent opinion in Wisconsin v. Pelican Insurance Co., ${ }^{87}$ where, in holding its own original jurisdiction limited to civil cases, the Court had said the relevant clause of article III gave jurisdiction only over cases that could otherwise have been brought outside the state whose law was being applied and that full faith would not require one

s1 Justice Peckham did say in Dorr that Downes was not controlling, but he did not say how the issue was different; he said only that there had been no opinion for the majority. Dorr, 195 U.S. at 154 (Peckham, J., concurring).

82 U.S. ConsT. art. IV, § 1.

${ }^{83}$ Act of May 26, 1790, 1 Stat. 122 (codified as amended at 28 U.S.C. $\$ 1738$ (1982)).

84 See Mills v. Duryee, 11 U.S. (7 Cranch) 481 (1813), discussed in D. CurrIE, supra note 3 , ch. 8.

${ }^{8 s}$ See D'Arcy v. Ketchum, 52 U.S. (11 How.) 165 (1851), discussed in D. CuRrIE, supra note 3, ch. 8; see also Pennoyer v. Neff, 95 U.S. 714, 729 (1878) ("full faith and credit" not required when rendering court lacked jurisdiction over parties or subject matter); D. CuRRIE, supra note 3, ch. 11 (discussing Pennoyer, its progeny, and procedural due process).

${ }^{86}$ Huntington v. Attrill, 146 U.S. 657, 683, 686 (1892).

${ }_{87} 127$ U.S. 265 (1888), cited in Huntington, 146 U.S. at 670-72, 685. 
state to enforce the penal judgments of another. ${ }^{88}$ The reason given in both cases seemed to be that the rule against enforcing foreign penal laws went to the jurisdiction of the enforcing court; it had long been said that the full faith and credit clause, though making the judgments of other states conclusive, gave no court jurisdiction to enforce them. ${ }^{89}$

This reasoning seemed to invite the states to ignore sisterstate judgments by denying their own courts jurisdiction, arguably depriving the clause of much of its effect. ${ }^{90}$ An alternative argument would have been that since the clause did not do away with the requirement that the rendering court satisfy traditional jurisdictional requirements, it did not do away with other traditional requirements either, including the rule about penal laws. ${ }^{91}$ One

88 127 U.S. at 289-92. Pelican Insurance was influenced by fear that the Supreme Court might be flooded with petty original suits. Id. at 300 . Gray naturally did not allude to this in Huntington.

${ }^{80}$ See Huntington, 146 U.S. at 685; Pelican Insurance, 127 U.S. at 291-92.

${ }^{90}$ See infra notes 98-105 and accompanying text (discussing Fauntleroy v. Lum, 210 U.S. 230 (1908)). However, Gray's principle that the clause did not require the assertion of jurisdiction seemed to be qualified by his sensible caveat that the decision that the law was penal, like the decision that a state had not made a contract it was accused of impairing, must be subject to Supreme Court review to prevent evasion of the full faith requirement. Huntington, 146 U.S. at 683-84; cf. D. CuRRIE, supra note 3, ch. 7 (discussing contract clause cases).

It seemed inconsistent with this insight, and with the similar conclusion reached in Hancock Nat'l Bank v. Farnum, 176 U.S. 640 (1900) (Brewer, J.), for the Court to hold at about the same time that whether one state had misinterpreted another's law did not raise a federal question meriting Supreme Court review. See Johnson v. New York Life Ins. Co., 187 U.S. 491 (1903) (Brown, J.); Glenn v. Garth, 147 U.S. 360 (1893) (Fuller, C.J.). There was no suggestion in either of these opinions, as there had been in Huntington, 146 U.S. at 683-84, that the clause distinguished between laws and judgments. Indeed, when the decisions were reaffirmed in 1909 , the Court expressly stated in dictum that a state constitution was entitled to as much credit as a judgment because it was a "public act[l]" within the meaning of the constitutional provisions. Smithsonian Inst. v. St. John, 214 U.S. 19, 28-29 (1909) (Brewer, J.). Moreover, though some language in Glenn had suggested that the difficulty lay in the limited categories of federal questions then subject to Supreme Court review under the governing statute, 147 U.S. at 367-68 (distinguishing nonreviewable questions of "construction" from reviewable questions of "validity" of state statutes); see also Act of Sept. 24, 1789, § 25, 1 Stat. 73, 85-87 (repealed 1928) (narrowly restricting the Court's power to review highest state court decisions on writ of error), later decisions went further, see Johnson, 187 U.S. at 496 (construction issue "not a Federal question"); Smithsonian, 214 U.S. at 29 (" $[\mathrm{I}] \mathrm{t}$ is settled that the mere construction by a state court of the statute of another State, without questioning its validity, does not deny to it the full faith and credit demanded by the constitutional provision."). But see B. Currie, Full Faith and Credit, Chiefly to Judgments: A Role for Congress, 1964 Sup. CT. REv. 89, 111 (approving the contrary view of some modern cases, e.g., Ford v. Ford, 371 U.S. 187 (1962), that the correctness of the state court's interpretation of the rendering state's law is a federal question).

${ }^{21}$ See D'Arcy v. Ketchum, 52 U.S. (11 How.) 165, 175-76 (1851) (discussing the traditional lack of respect for the judgment of a court rendered without service of process: "There was no evil in this part of the existing law, . . . and in our opinion Congress did not 
might in response question whether recognition of traditional exceptions was consistent with a clause designed to make mandatory what had once been a matter of comity; $;^{22}$ but the same objection could have been leveled against the longstanding jurisdictional exception. ${ }^{93}$

To show that the New York judgment in Huntington was not penal, Gray quoted at tiresome length from a flock of decisions, some of which had concluded that "penal" claims did not include private damage actions even though the measure of recovery was not apportioned to the harm the defendant had caused..$^{94}$ Unfortunately, however, he had to admit there was a split of authority. ${ }^{95}$ That made it impossible to determine what "penal" really meant without understanding the purpose of the rule, and Gray spent so much time quoting other people's conclusions that he never got around to saying what that purpose was. An examination of the reasons usually given to support the rule suggests that Gray was right not to consider the law before him "penal,"96 but his opinion

intend to overthrow the old rule ....."). In support of an exception for penal judgments one might also argue that article IV already provided for enforcement of criminal laws by the distinct means of extradition. This argument would support an even narrower definition of "penal" laws than that taken by the Court in Huntington. For a discussion of the different definitions of "penal," see infra note 96.

${ }_{92}$ See Mills v. Duryee, 11 U.S. (7 Cranch) 481, 485 (1813) (Story, J.) ("Were . . . judgments . . considered prima facie evidence only, this clause in the constitution would be utterly unimportant and illusory."); 3 J. STORY, supra note 35, \$§ 1303-04; cf. Kentucky v. Dennison, 65 U.S. (24 How.) 66, 107-09 (1861) (making similar argument in construing extradition clause of article IV), discussed in D. CuRRIE, supra note 3 , ch. 8.

${ }^{83}$ See supra note 85 and accompanying text (discussing D'Arcy v. Ketchum, 52 U.S. (11 How.) 165 (1851)). Justice Story, who as indicated was a firm believer that the merits of the rendering court's decision could not be reexamined, argued without explanation that jurisdiction was different. 3 J. STORY, supra note $35, \S 1307$.

94 146 U.S. at $666-69,673-82$.

9s Id. at 679 (dismissing contrary cases as having given "no reasons . . . for considering the statute a penal law in the strict, primary and international sense").

9s See Restatement of Conflict of Laws $\$ 611$ comment a (1934) (adopting Huntington's definition: a penalty is "punishment for a civil wrong," not compensation for loss suffered by injured party); Leflar, Extrastate Enforcement of Penal and Governmental Claims, 46 HARv. L. REv. 193, 211, 225 (1932) (explaining the rule largely in terms of provisions requiring local juries and the availability of extradition). There was also a strong argument that the basic reasons for the penal exception were inapplicable to suits for enforcement of judgments. See Albert Ehrenzweig, Conflict of LAWs 204-205 (1962); cf. Milwaukee County v. M.E. White Co., 296 U.S. 268, 275-77 (1935) (holding a tax judgment entitled to full faith and credit despite an assumed rule that tax claims not reduced to judgment need not be enforced: "We can perceive no greater possibility of embarrassment [by conflicting interpretations of sister-state laws] in litigating the validity of a judgment for taxes and enforcing it than any other for the payment of money."). The traditional rule seems nevertheless to have embraced such suits. See Joseph STORY, CoNflict of Laws $\S \S 608-09,628$ (1834). Gray said only that " $[t]$ he essential nature and real foundation of a 
did not give satisfactory reasons for that conclusion. ${ }^{97}$

\section{B. Fauntleroy v. Lum}

For all its talk about how the full faith and credit clause was not absolute, Huntington had required a state to respect a judgment, as did the even more famous 1908 decision in Fauntleroy $v$. Lum.98

Fauntleroy had recovered a Missouri judgment on a Mississippi contract respecting cotton futures. A Mississippi court refused to enforce the judgment, and the Supreme Court reversed. Marshall had held that one state must give the judgment of another's competent court the same credit it had at home; the judgment was conclusive in Missouri; and that, said Holmes, was that.98

For the four dissenters, Justice White raised two interesting objections. Not only had Gray suggested in Huntington and in Pelican Insurance that the reason one state need not enforce another's penal judgments was that the full faith clause did not require it to take jurisdiction; ${ }^{100}$ as White noted, Holmes himself had written for a unanimous Court in 1903 to hold squarely that a state could decline jurisdiction to enforce an ordinary civil judgment. ${ }^{101}$ Holmes responded that the Mississippi law forbidding enforcement of futures contracts in Fauntleroy created a "rule of decision" rather than a bar to jurisdiction; ${ }^{102}$ he did not explain what earthly significance this distinction had to the terms or purposes of the full faith clause. ${ }^{103}$ If Holmes had thought better of his earlier decision,

cause of action are not changed by recovering judgment upon it." Pelican Insurance, 127 U.S. at 292.

${ }^{97}$ Fuller dissented, arguing without reasoning that whether the judgment was penal was not a federal question. Huntington, 146 U.S. at 688 .

28210 U.S. 230 (1908).

9 Id. at 236-37 (citing Hampton v. McConnel, 16 U.S. (3 Wheat.) 234 (1818), which had relied on Mills v. Duryee, 11 U.S. (7 Cranch) 481 (1813), discussed supra note 92).

${ }^{100}$ See supra notes 86-91 and accompanying text.

${ }^{101}$ See Fauntleroy, 210 U.S. at 245 (White, J., joined by Harlan, McKenna and Day, JJ., dissenting) (citing Anglo-American Provision Co. v. Davis Provision Co., 191 U.S. 373 (1903)). The statute in Anglo-American had allowed one foreign corporation to sue another only on a local cause of action. 191 U.S. at 373.

${ }^{102} 210$ U.S. at 234-36.

${ }^{103}$ If Holmes's rationale was that a jurisdictional dismissal would not bar a subsequent suit elsewhere, he drew the wrong line; the question should have been whether the dismissal, jurisdictional or not, was meant to bar only the remedy or the substantive right as well. $C f$. Bradford Elec. Light Co. v. Clapper, 286 U.S. 145, 160 (1932) (dismissal of foreign cause of action on ground of public policy merely denies a remedy, leaving unimpaired underlying right); Warner v. Buffalo Drydock Co., 67 F.2d 540, 541 (2d Cir. 1933) ("[T]he judgment of the court of a foreign state which dismisses a cause of action because of the statute of limitations of the forum is not a decision upon the merits and is not a bar to a new action upon 
he would have been on firm ground to say so:104 it is hard to conclude that a state has fulfilled its statutory duty to give a judgment the same credit it would have had where rendered, as the implementing statute requires, when the state refuses to enforce the judgment at all. ${ }^{108}$

White's other tack was to argue that the clause did not require respect for all valid judgments even if the enforcing court did have jurisdiction. ${ }^{108}$ On this point he claimed the authority of the penal exception recognized in Pelican Insurance, ${ }^{107}$ which Holmes, rather than distinguishing, dismissed as dictum. ${ }^{108}$ Dictum in the technical sense it was, though it had been an important part of the Court's explanation for the actual holding; it was also dictum when repeated in Huntington, ${ }^{109}$ which oddly enough neither side cited at all.

White did not contend that the judgment in Fauntleroy was penal. He argued instead that its enforcement would deprive Mississippi of the power to legislate with respect to activities within her own borders; Mississippi had expressed a strong public policy against gambling in cotton futures, and the Court's decision al-

the identical claim in the courts of another state."). However, in many cases even a dismissal barring only the remedy would leave the judgment holder without practical recourse, just as he would have been before the full faith clause was adopted.

${ }^{104}$ As he later did in Kenney v. Supreme Lodge, 252 U.S. 411, 414-15 (1920), despite an unconvincing attempt to distinguish Anglo-American on the basis of "the views about foreign corporations that had prevailed unquestioned since Bank of Augusta v. Earle, [38 U.S. (13 Pet.) 517 (1839)]." Holmes stated, "[A] State cannot escape its constitutional obligations by the simple device of denying jurisdiction . . . to courts otherwise competent." Kenney, 252 U.S. at 415.

105 See B. Currie, supra note 90, at 119-20; 2 Records or the Federal Convention of 1787, at 447 (M. Farrand rev. ed. 1937) ("Mr. Wilson \& Docr. Johnson supposed the meaning to be that Judgments in one state should be the ground of actions in other states ....") [hereinafter cited as ConvEnTION REcords]. The holding that full faith did not require a state to enforce foreign judgments also seems irreconcilable with the almost contemporaneous holding in General Oil Co. v. Crain, 209 U.S. 211 (1908), discussed in D. Currie, supra note 1, at 386 n.372, that a state could not close its courts on sovereign immunity grounds to suits to enjoin state officers from violating federal rights. Cf. D. CuRRIE, supra note 3 , chs. 5,7 (discussing the extent to which a law abridging a preexisting remedy for breach of contract is an impairment of contracts in violation of article I, section 10).

106210 U.S. at 241-44 (White, J., dissenting).

${ }^{107}$ Id. at 242-44. Pelican Insurance is discussed supra notes 87-90 and accompanying text.

108210 U.S. at 237 (majority opinion). Holmes might have pointed out that Gray had explained the penal exception as part of the general rule that the Constitution did not require a state court to take jurisdiction to enforce foreign judgments. See supra notes 87-90 and accompanying text. But see Kansas v. Colorado, 206 U.S. 46, 83 (1907) (dictum) (describing Pelican Insurance, in the teeth of Gray's opinion in that case, as "no denial of the jurisdiction of the court, but a decision upon the merits").

${ }^{109}$ See 146 U.S. at 670-72, discussed supra notes 87-90 and accompanying text. 
lowed that policy to be frustrated by filing suit in another state.110 An exception for laws contrary to the public policy of the forum, White suggested, was as much a part of traditional conflict-of-laws doctrine as the penal exception itself. ${ }^{111}$ If the full faith and credit clause-which in conformity with his unsympathetic interpretation White kept referring to as the "due faith and credit clause"-did not override traditional exceptions for lack of jurisdiction or for penal claims, parallelism would suggest that it did not override the traditional public policy exception either. ${ }^{112}$

White's concern seemed to raise a substantial doubt: could the framers have meant to deny a state the power to legislate for its own affairs? ${ }^{113}$ The unanimous decision in Allgeyer $v$. Louisiana ${ }^{114}$ eleven years before might be thought to have provided an answer: there was no need to distort the full faith and credit clause to avoid reaching absurd results because the state's interest was adequately protected by the ability of the defendant to argue in the original proceeding that due process required the application of Mississippi law. ${ }^{115}$

The weak spot in this argument is that there seems to have been no such limit on state choice-of-law decisions before the fourteenth amendment was adopted in 1868. The later view that the full faith clause's own reference to "public Acts" required respect for the law of the appropriate state ${ }^{116}$ may be out of line with the intentions of the framers. ${ }^{117}$ Fauntleroy can thus most effectively

110 See 210 U.S. at 239-41 (White, J., dissenting).

${ }^{111}$ Id. at 241-43. See J. Story, supra note 96, §§ 25, 36, 38, 259; 2 Joseph Beale, The CoNFLiCT OF LAWS $\$ 445.1$ (1935).

112 See, e.g., Fauntleroy, 210 U.S. at 242 ("[T]he purpose of the due faith and credit clause was ... simply to make obligatory that duty which, when the Constitution was adopted rested . . . in comity alone.").

113 For a more recent version of this argument, see RESTATEMEnT (SECOND) of Conflict of Laws $\S 103$ comment b (1971) (allowing a public policy exception in "extremely rare" instances involving "too large a sacrifice" of state interests), and see the vigorous response in Ehrenzweig, The Second Conflicts Restatement: A Last Appeal for Its Withdrawal, 113 U. PA. L. Rev. 1230, 1240 (1965) (advocating strict adherence to Fauntleroy).

11165 U.S. 578 (1897), discussed in D. Currie, supra note 1, at 375-78.

115 See Robert Leplar, American Conplicts Law $\$ 75$ (3d ed. 1977) ("Appeal rather than collateral attack was the losing party's proper remedy . . ..").

${ }^{116}$ See, e.g., Bradford Elec. Light Co. v. Clapper, 286 U.S. 145, 154-55 (1932).

117 The origin of. the "public Acts" language was a concern for individual insolvency acts that were similar in effect to judicial judgments. See 2 ConvenTron RecorDs, supra note 105, at 447 (Messrs. Wilson and Johnson) ("acts of the Legislatures should be included, for the sake of Acts of insolvency \&c"); Comment, Conflict of Laws-Full Faith and Credit as Applied to Statutes, 51 Mrch. L. REv. 267, 269 (1952). Justice Story's influential treatises spoke of full faith and credit only in the context of judgments. J. STORY, supra note 96, $\S 609$. He did not suggest that the clause qualified in any way the applicability to states of 
be defended on the ground that a public policy exception could easily have destroyed the clause altogether: if a state were free to reject any judgment contrary to its own policy, we would return to the situation the clause was designed to avoid.

Some infringement of one state's interest by another, in other words, may have been the price of full faith and credit. Holmes said none of this; in his lofty way he managed hardly to respond at all to White's provocative challenge.

\section{Clarke v. Clarke}

Whatever the gaps in Holmes's reasoning, it seemed clear after Fauntleroy -with some uncertainty as to the status and nature of the penal exception-that full faith required any court with jurisdiction to give the judgment of another state's court with jurisdiction the same effect it would have had in the state where it was rendered. ${ }^{118}$ Most of the Fuller Court's decisions in this field, however, dealt with the question whether the rendering court had had jurisdiction to begin with.

The first such decision came in 1900, when in Clarke $v$.

his general principle that "whatever force and obligation the laws of one country have in another, depends solely on the laws, and municipal regulations of the latter." Id. at § 23; see also 3 J. STORY, supra note 35, §§ 1297-1307. Indeed, Gray had seemed to say in Huntington that nothing in the clause required enforcement of foreign claims not reduced to judgment. See supra note 90 . But suggestions of the opposite theory were already appearing. See Atchison, T. \& S.F. Ry. v. Sowers, 213 U.S. 55, 66-68 (1909), discussed infra note 126; El Paso \& N.E. Ry. v. Gutierrez, 215 U.S. 87, 92-93 (1909); Olmsted v. Olmsted, 216 U.S. 386, 394-95 (1910). A notable example is the flat unexplained dictum in Smithsonian Inst. v. St. John, 214 U.S. 19 (1909), relying upon the assumption in an earlier case that "public Acts" included a statute incorporating an individual railroad and finding there had been no denial of full faith and credit. Id. at 28-29 (citing Chicago \& Alton R.R. v. Wiggins Ferry Co., 119 U.S. 615, 622 (1877) (Waite, C.J.)). In Bratnerd CuRrie, Selected Essays on the Conflict of Laws (1963), Professor Currie argued that to limit the clause to "legislative decrees of insolvency and divorce ... not only trivializes the constitutional provision but is in the teeth of clear evidence indicating that the final reference to 'public Acts' was intended to exclude just such legislation from coverage." Id. at $198 \mathrm{n} .35$ (emphasis in original) (citations omitted). The "clear evidence" referred to was Professor Crosskey's speculation that the insertion of the suggestive word "public" was based on the same antipathy to special legislation that induced the framers to limit Congress to enactment of "uniform" bankruptcy laws. 1 William Crosskey, Politics and the Constitution in the History of the United States 542-44 (1953).

118 See Sistare v. Sistare, 218 U.S. 1 (1910) (White, J.) (reaffirming the holding of Barber v. Barber, 62 U.S. (21 How.) 582 (1859), that alimony decrees were entitled to full faith, reversing Connecticut's reading of New York law, cf. supra note 90 (discussing Huntington), and requiring enforcement of past-due sums under an alimony decree though it had been modifiable before the sums fell due); cf. Lynde v. Lynde, 181 U.S. 183 (1901) (Gray, J.) (refusing to require enforcement of a similar decree as to future installments because the power to modify deprived the decree of binding force even in the rendering state). 
Clarke ${ }^{119}$ the Court unanimously upheld the refusal of a Connecticut court to honor a South Carolina decree respecting the inheritance of Connecticut land. For the most part, Justice White's opinion reads remarkably like his later dissent in Fauntleroy: if Connecticut had to recognize a South Carolina decree, she could not control the ownership of land within her own borders. ${ }^{120}$ Since all parties concerned appeared to be from South Carolina, ${ }^{121}$ the modern observer may be inclined to take issue with White's conclusion that the substance of the matter was none of South Carolina's business. ${ }^{122}$ But the more striking fact is that, despite the similarity of his arguments in the two cases, White did not invoke Clarke at all when he dissented from Fauntleroy eight years later.

The explanation is that the Court had not held in Clarke that a judgment could be collaterally attacked for applying the wrong law; as the last paragraph of the opinion reveals, the decision was based upon "a want of jurisdiction . . . over the particular subjectmatter." 123 This conclusion, however, looks at least as peculiar today as the argument that the law of the situs must control. As noted, all the parties seemed to be South Carolinians, and normally the mere fact that foreign law is to be applied does not deprive an otherwise convenient forum of the power to hear the case. ${ }^{124}$ Indeed, within nine years after Clarke the Court was to hold in Atchison, Topeka \& Sante Fe Railway v. Sowers ${ }^{125}$ that one sovereign could not prevent the courts of another from entertaining claims based upon the former's law. ${ }^{126}$ The difference be-

120178 U.S. 186 (1900).

120 Id. at 190-92; see also Olmsted v. Olmsted, 216 U.S. 386, 394-95 (1910) (Day, J.) (holding full faith did not require the state where land was situated to recognize a statute of another state respecting the right to inherit land: "The full faith and credit clause ... applies with no more effect to the legislative acts of a foreign State than it does to the judgments of the Courts of such State .... The legislature of Michigan had no power to pass an act which would affect the transmission of title to lands located in the State of New York."). For a general statement of the traditional primacy of the law of the situs, see J. STORY, supra note $96, \S 483$.

121178 U.S. at 186.

122 See, e.g., Mofratt Hancock, Studies in Modern Choice-or-Law: Torts, Insurance, Land Titres chs. 10-12 (1984); Baxter, Choice of Law and the Federal System, 16 Stan. L. Rev. 1, 15-17 (1963).

${ }^{123} 178$ U.S. at 195.

124 See H. Goodrich \& E. Scoles, Conflict of Laws § 96, at 177 (4th ed. 1964); J. STORY, supra note $96, \S 538$.

${ }^{125} 213$ U.S. 55 (1909) (Day, J.).

126 Id. at 70-71; cf. Hughes v. Fetter, 341 U.S. 609, 611-13 (1951) (holding full faith and credit forbade one state to dismiss as contrary to public policy wrongful-death action based on another's law). The basis for the Sowers decision was that, although the place where an accident occurred had power to determine the substantive rights arising out of the occur- 
tween the two cases lay in the traditional distinction between transitory and local actions: an action for personal injuries could be brought anywhere, ${ }^{127}$ but actions respecting land could be brought only where the land lay. ${ }^{128}$ Modern observers tend to be unsympathetic to the local-action rule at least in its more extreme applications, ${ }^{129}$ but it was firmly established when Clarke was decided; ${ }^{130}$ and that meant that under traditional principles the South Carolina court had lacked jurisdiction. ${ }^{131}$

From today's perspective everything about Clarke looks wrong. It is hard to see why Connecticut should have sole authority to regulate the descent of property among South Carolina citizens. It is hard to see why, even if it has, South Carolina should lack jurisdiction to determine the controversy according to Connecticut law. Finally, it is hard to see why, even if the defect was jurisdictional, the objection should not as a general rule have to be raised in the South Carolina proceeding. ${ }^{132}$ All of these things,

rence, it could not determine the jurisdiction of a court outside its borders. 213 U.S. at 70 . Holmes, whom McKenna joined in dissent, thought the limitation was a "condition to the right" and not a regulation of foreign jurisdiction. Id. at 71. For criticism of the decision based on modern interest analysis, see B. CURRIE, supra note 117, at 311-26. Of additional significance is the unexplained assumption of all the Justices in Sowers that the reference to "public Acts" in the full faith clause and its implementing statute included general statutes. See supra note 117 (discussing what was meant by "public Acts").

127 See Sowers, 213 U.S. at 67.

${ }^{128}$ See, e.g., Livingston v. Jefferson, 15 F. Cas. 660 (C.C.D. Va. 1811) (No. 8,411) (action for trespass); $3 \mathrm{~J}$. BEALE, supra note 111, $\$ 613.1$ ("only the state where the land lies has control over the res, and consequently power to affect interests therein").

128 Most of the criticism has been in the context of actions for trespass to land, where the doctrine has been increasingly discarded. See, e.g., Reasor-Hill Corp. v. Harrison, 220 Ark. 521, 249 S.W.2d 994 (1952); H. GoodRICH \& E. Scoles, supra note 124, § 96; see also A. EHRENZWEIG, supra note 96, at 83 ("Jurisdiction in rem presupposes a situs of the res within the boundaries of the forum state."); $c f$. Restatement (Second), supra note $113, \S 87 \&$ comment a (preserving the rule where title to land is at stake). The sovereign power rationale that underlies this presupposition, however, see supra notes $120,126,128$, is unpersuasive in a country blessed with a Constitution requiring respect for sister-state judgments. $C$ f. J. STORY, supra note $96, \S 551$ (conceding that the Roman rule allowing land cases to be determined by a domiciliary court made sense in a system in which judgments "would be everywhere respected and obeyed").

130 See J. STORY, supra note 96 , § 554.

131 The South Carolina court had attempted to avoid the traditional rule by invoking the fiction that the owner's death had by "equitable conversion" turned the land into personal property; the Supreme Court declined to endorse such a ruse. Clarke, 178 U.S. at 19192; see M. HaNcock, supra note 122, at 233 n.26.

132 The policy of repose underlying full faith and credit is as applicable to jurisdictional questions as it is to the merits, and modern cases have held that even jurisdictional questions can be foreclosed under the full faith and credit clause once actually litigated. See, e.g., Durfee v. Duke, 375 U.S. 106 (1963). For an approving view, see B. Currie, supra note 90 , at 105 . The earlier view was the more formalistic one that a court without jurisdiction had no more power to determine its own jurisdiction than to determine anything else. See 
however, seem to have been pretty standard in $1900 .^{133}$ Therefore, though White's lack of explanation and his stress on Connecticut's sole power to regulate the transaction seemed to invite a denial of recognition on choice-of-law grounds in Fauntleroy $v$. Lum, the Court in the latter case appears to have recognized Clarke for what it really was: a straightforward application according to prevailing jurisdictional principles of the established rule that no credit was due to the judgment of a court without jurisdiction. ${ }^{134}$

\section{Atherton v. Atherton}

In Pennoyer v. Neff, ${ }^{135}$ in 1878 , the Supreme Court had refused full faith and credit to a judgment for breach of contract on the ground that failure to serve the defendant with process within the state had deprived the rendering court of jurisdiction. In Ath-

Thompson v. Whitman, 85 U.S. (18 Wall.) 457, 468 (1873) (Bradley, J.). On top of that, White added in Clarke that the party against whom the South Carolina decree was asserted had not been sui juris at the time of the South Carolina proceeding (she was a minor) and that no one before the court had had authority to speak for her in respect to out-of-state land. 178 U.S. at 193.

133 Even at the time of Clarke, however, there were so many decisions employing available devices for escaping from the unpalatable consequences of the standard learning that Professor Hancock was able to describe the local-action rule as "a mere textbook aphorism that did not accurately represent . . . practice." M. HANcock, supra note 122 , at 337.

134 The same is true of the much debated Fall v. Eastin, 215 U.S. 1 (1909), where in an obscure and turgid McKenna opinion the Court over the unexplained dissents of Harlan and Brewer held that Nebraska need not respect a deed to Nebraska land executed by an officer of the state of Washington pursuant to a Washington decree respecting the division of the property of Washington spouses incident to a divorce. Despite the similarity of the case to Clarke, the Court acknowledged that the Washington court had had jurisdiction to order the husband to convey the land to his wife and that if he had complied the deed would have been respected. Id. at 5-6, 8, 10-11. This suggests that even traditional rules were not so protective of the interests of the situs as Clarke might have led one to believe. The trouble was that the Washington officer had attempted to convey the land itself, and that only the situs could exercise jurisdiction to affect the land directly. McKenna seemed to think the distinction as silly as it sounds, but felt bound by it anyway. See id. at 11-12. A later commentator, while branding the opinion "undiscriminating, confused, unworthy, reluctant, and ambiguous," has found justification for the distinction in what he thought was the greater interference of a foreign commissioner's deed with the functioning of the recording system. See B. Currie, Full Faith and Credit to Foreign Land Decrees, 21 U. CHI. L. REv. 620, 639-40, 648 (1954). For questions as to this analysis, see R. CrAMton, D. CuRrIE, \& H. Kay, Conflict of Laws: Cases-Comments-Questions 719 (3d ed. 1981).

On this point, see also Brown v. Fletcher's Estate, 210 U.S. 82, 94-95 (1908) (Brewer, J.) (holding in accord with traditional understanding that a judgment against an administrator in a suit for an accounting in one state was not binding on an executor of the same decedent elsewhere, on the ground that each state had exclusive jurisdiction to administer property within its borders). For a criticism in modern terms, see D. Currie, The Multiple Personality of the Dead: Executors, Administrators, and the Conflict of Laws, 33 U. CHI. L. REv. 429 (1966).

${ }^{135} 95$ U.S. 714 (1878), discussed in D. CURRIE, supra note 3, ch. 11. 
erton $v$. Atherton, ${ }^{136}$ in 1901, the Court held this rule inapplicable to divorce proceedings, upholding the power of a state where both husband and wife had lived to exercise jurisdiction over an absent spouse who had allegedly abandoned her husband. In two companion cases, however, the Court denied the power of a state in which neither party was domiciled to affect the rights of an absent spouse. $^{137}$

These results are easily explicable in modern terms. Atherton was the typical case for which today's longarm statutes were designed: it seems entirely consonant with the later due process tests of "minimum contacts" and "fair play and substantial justice" to expect an alleged wrongdoer, if actually notified, to litigate at the scene of the wrong. ${ }^{138}$ The companion cases presented the other side of the coin: it is unfair to haul a defendant to a forum with which he or she has had no voluntary contact at all, ${ }^{139}$ and a judgment void for want of due process is entitled to no faith anywhere. ${ }^{140}$

Justice Gray, however, did not write in these terms. Pennoyer had been based on tradition, not on fairness; due process at that time meant historical process. ${ }^{141}$ Indeed Gray did not speak of due

136181 U.S. 155 (1901).

${ }^{137}$ Bell v. Bell, 181 U.S. 175 (1901); Streitwolf v. Streitwolf, 181 U.S. 179 (1901).

${ }^{138}$ See International Shoe Co. v. Washington, 326 U.S. 310, 316 (1945); see also WorldWide Volkswagen Corp. v. Woodson, 444 U.S. 286 (1980) (adding that the due process clause served also "as an instrument of interstate federalism"); cf., e.g., McGee v. International Life Ins. Co., 355 U.S. 220, 223 (1957) ("It is sufficient for the purpose of due process that the suit was based on a contract which had substantial connection with that State.").

139 See Hanson v. Denckla, 357 U.S. 235, 254 (1958); D. Currie, The Growth of the Long Arm: Eight Years of Extended Jurisdiction in Illinois, 1963 U. ILL. L.F. 533, 548-50.

${ }^{140}$ See Hanson v. Denckla, 357 U.S. 235, 255 (1958); 28 U.S.C. § 1738 (1982) ("the same full faith and credit in every court . . . as they have . . . in the courts . . . from which they are taken").

${ }^{142}$ The force of tradition had been relaxed before the 1901 cases by Hurtado v. California, 110 U.S. 516 (1884), discussed in D. CuRRIE, supra note 3, ch. 11, which held that the historically requisite grand jury was not part of due process because it was not "fundamental." 110 U.S. at 535. The application of this standard to the particulars of traditional personal-jurisdiction rules had yet to be worked out in detail. An interesting start had been made, however, in the famous case of York v. Texas, 137 U.S. 15 (1890) (Brewer, J.), where the Court held over the unexplained dissents of Bradley and Gray that due process did not require a state to permit a special appearance to challenge the assertion of jurisdiction over the person. Conceding that the special appearance was sanctified by tradition, the Court said it was enough that the new rule secured "the substance of right . . . without unreasonable burden": the defendant could have protected his right not to be sued in Texas by staying away and attacking the judgment when the plaintiff sued on it in another state. Id. at 20-21. Brewer did not acknowledge that he could do so only by foregoing the opportunity to make a defense on the merits in case his jurisdictional attack failed. Cf. Fauntleroy v. Lum, 210 U.S. 230 (1908) (forbidding collateral attack on merits), discussed supra notes 98-103 and accompanying text. Today it might well be found "unreasonable" to require a defen- 
process at all. Though in holding the judgment entitled to respect he implicitly found it did not offend due process, he was concerned instead with the more ancient principle that, regardless of domestic validity, full faith was not required if traditional jurisdictional standards had not been met. ${ }^{142}$

Just what tradition dictated in the divorce cases was unclear. Gray quoted at pedantic length from a number of state cases upholding jurisdiction over absent spouses in the state where the other lived, ${ }^{143}$ added Supreme Court dicta to the same effect, ${ }^{144}$ and invoked the authority of influential treatises. ${ }^{145}$ As in Hunt-

dant to surrender one defense in order to assert another. See Note, Developments in the Law: State-Court Jurisdiction, 73 Harv. L. Rev. 909, 991-97 (1960). The common law, however, was full of such unappetizing choices. For example, the defendant who challenged the legal basis of the plaintiff's case by demurring thereby lost the right to dispute the facts. See D. Louisell, G. Hazard, \& C. Tait, Cases and Materials on Pleading and Procedure 84 (5th ed. 1983); cf. Trono v. United States, 199 U.S. 521 (1905) (holding a defendant who appealed a conviction waived double-jeopardy objections to review of his acquittal of another charge in the same case), discussed supra note 15. See also Roller v. Holly, 176 U.S. 398 (1900) (Brown, J.) (holding five days notice to a Virginian to defend in Texas not "reasonable" and thus not due process, but evidently by construing the traditional notice requirement as a requirement of reasonable notice).

142 See D'Arcy v. Ketchum, 52 U.S. (11 How.) 165 (1851), discussed supra note 85 and accompanying text. Interesting examples of this principle during the Fuller years include Chicago, R.I. \& P. Ry. v. Sturm, 174 U.S. 710 (1899) (McKenna, J.), and the well-known case of Harris v. Balk, 198 U.S. 215 (1905) (Peckham, J.), both holding judgments based on so-called foreign attachment entitled to full faith and credit. In both cases the first suit had been brought to collect on an obligation owed by a person beyond the reach of service of process by garnishing a debt owed to the absent person by an individual within the forum state. Without discussing the implicit due process issue, the Court in Sturm affirmed the jurisdiction of the court to render a judgment appropriating the garnishee's obligation and discharging him from further liability to the absent party. It did so on the basis partly of historical acceptance, partly of the policy in favor of providing a forum, and partly of physical power over the garnishee. Sturm, 174 U.S. at 714-16. In Sturm the garnishee had been a resident of the forum state. In Harris he was not; though history revealed a lack of consensus on the question, the Court held residence immaterial because any state where the debtor was found had power to extract his money. Harris, 198 U.S. at 222.

Under the modern test of fair treatment of the absent party these decisions are quite untenable, and Harris has been overruled. See Shaffer v. Heitner, 433 U.S. 186 (1977); see also D. Currie, supra note 139, at 584. Even in terms of power the Court's reasoning in Harris seems misguided: although the forum could physically do as it pleased to the unfortunate garnishee, it had no physical power over his absent creditor, and physical power over intangible "property" is pure fiction.

14s Atherton, 181 U.S. at 164-69.

14 Id. at 163-64.

145 Id. at 164, 166 (citing Story (in a quotation from an earlier decision), Kent, and Cooley). To the extent that the traditional rule requiring service within the state reflected the supposed futility of entering a judgment that could not be executed-a concern misplaced in a federation with a full faith requirement-divorce cases were distinguishable: the divorce decree would effectively liberate the plaintiff spouse whether or not physical consequences could be visited upon the defendant or his assets. 
ington $v$. Attrill, ${ }^{146}$ however, he had to concede there was contrary state authority. ${ }^{147}$ As in Huntington, moreover, he resolved the conflict in favor of what he thought the more appropriate rule: "To hold otherwise would make it difficult if not impossible, for the husband to obtain a divorce for the cause alleged, if it actually existed."148 The companion cases were resolved by mere fiat: "No valid divorce ... can be decreed on constructive service by the courts of a State in which neither party is domiciled."149

Thus the Court seemed to read the full faith and credit clause to require it to develop what was essentially a federal common law of state-court jurisdiction, confected from historical practice and shaped in the mold of public policy. On the facts of Atherton and its companion cases the Court by this method and with very little explanation attained results fully in accord with the modern due process calculus of fair play-if one puts to one side the Court's strange indifference to whether the defendant had actually been given notice of the proceeding. ${ }^{150}$

\section{E. Andrews v. Andrews}

Two years later, over three unexplained dissents, Justice White wrote for the Court in Andrews v. Andrews ${ }^{151}$ to hold that no credit was due to a divorce decreed by a court of a state in which neither party lived even if the defendant did not object to the exercise of jurisdiction. We have discussed the earlier divorce cases in terms of jurisdiction over the person, which can be waived

${ }^{146} 146$ U.S. 657 (1892), discussed supra notes 86-97 and accompanying text.

${ }^{147}$ Atherton, 181 U.S. at 169-70.

${ }^{148}$ Id. at 173. The dissenters turned this argument around, assuming the facts to be as found by a court in the state to which the wife had moved: "That a husband can drive his wife from his home" and then divorce her there was "at war with sound principle and the adjudged cases." Id. at 175 (Peckham, J., joined by Fuller, C.J., dissenting). In voting to sustain the judgment of the wife's state, the dissenters showed that they were by no means hostile to the assertion of jurisdiction over an absent defendant; in their view the jurisdiction of both courts depended on the merits.

149 Bell v. Bell, 181 U.S. 175, 177 (1901). Streitwolf v. Streitwolf, 181 U.S. 179 (1901), was decided on the authority of Bell. Id. at 182-83.

${ }_{150}$ See Atherton, 181 U.S. at 171-72 (saying there was a "presumption" that the wife had received an unanswered letter of notification, but finding it irrelevant if she had not because the real question was not actual notice but whether "reasonable steps had been taken to give her notice"). At least one of the cases relied on had said that service by publication would suffice on a defendant whose residence was unknown. See id. at 166-67 (citing Ditson v. Ditson, 4 R.I. 87 (1856)). For the modern view of the notice question, see Mullane v. Central Hanover Bank \& Trust Co., 339 U.S. 306 (1950).

151188 U.S. 14 (1903). Brewer, Shiras, and Peckham dissented. Holmes, who had taken his seat after argument, took no part. Id. at 42. 
because it relates primarily to the convenience of the litigant. ${ }^{162}$ But in Andrews the Court explained that Atherton and its companion cases had held domicile essential to jurisdiction over the subject matter-and a want of subject-matter jurisdiction could not be cured by consent. ${ }^{153}$

Like the decision in Clarke $v$. Clarke that controversies over land titles were not transitory, ${ }^{154}$ this characterization was out of line with the practice governing most lawsuits; analogy to tort or contract cases would suggest that any court could divorce a New York couple willing to litigate there so long as New York law was applied. As Clarke showed, however, there were exceptions. And, whether or not the exception regarding land made sense, Justice White revealed in Andrews why there was a special problem in divorce cases. The marriage relation was "so interwoven with public policy that the consent of the parties is impotent to dissolve it contrary to the law of the domicil."15s If the parties could achieve the same result by "perpetrating a fraud" on that law "by temporarily sojourning in another State," then "all efficacious power on the subject of divorce [would] be at an end."156

In short, in the ordinary case any interest the state of the tort or contract may have in the application of its own law is to some degree protected by the parties' incentive to insist on application of provisions that favor them; ${ }^{157}$ however, in a state with strict divorce laws both parties are likely to be hell-bent to frustrate state policy. If such laws were not to be evaded at pleasure, some way had to be found to allow the courts to protect the state's interest despite the wishes of the parties, and the label of subject-matter jurisdiction admirably filled the bill. In the first place, it permitted the court in which a divorce was sought to raise the question of domicile on its own motion. Moreover, under the view prevailing at the time of Andrews, subject-matter jurisdiction was always open to collateral attack. As in Andrews itself, the state of domicile could protect its own interest, even if the other court did not, by refusing to recognize the decree.

${ }^{162}$ See Note, supra note 141, at 997; FED. R. Crv. P. 12(h)(1).

163188 U.S. at 39-41; cf. Mansfield, C. \& L.M. Ry. v. Swain, 111 U.S. 379 (1884) (lack of diversity jurisdiction not curable by consent of parties); FED. R. Crv. P. 12(h)(3) (same).

154 See supra notes 119-34 and accompanying text.

165 Andrews, 188 U.S. at 41.

${ }^{158}$ Id. at 38, 32; see also J. SToRY, supra note 96, § 226.

${ }^{157}$ Even in such a case, as Fauntleroy shows, White argued for protection against the power of the forum to disregard the applicable law. See supra notes 106-117 and accompanying text. 
With eighty years of hindsight, it may be possible to improve on White's solution to the problem. The jurisdictional label achieved the desired result at the risk of denying the parties a possibly convenient forum; all the Court had to say was that choiceof-law decisions, like some jurisdictional ones, could not be left to the parties in divorce cases. ${ }^{158}$ That kind of flexibility, however, was uncommon in turn-of-the-century jurisprudence ${ }^{159}$ and did not reflect the traditional rules the Court seemed to think were the measure of full faith and credit. Furthermore, the cases in which it was a hardship for the parties to resort to their own courts must have been relatively rare. ${ }^{160}$ Andrews came up with an effective solution to the perennial problem of collusive divorce and persuasively explained its reasons.

\section{F. Haddock v. Haddock}

Yet another variation on the divorce problem was presented by the landmark case of Haddock v. Haddock ${ }^{161}$ in 1906. This time the husband had moved from the marital domicile in New York to Connecticut, where he had procured an ex parte divorce. New York refused to recognize the decree, and in another White opinion the Court affirmed over four dissents. ${ }^{162}$

To White the relevant principle was the one he had put forth in Andrews: if the Connecticut decree were entitled to recognition, New York could not regulate the marriage relations of her own citizens. ${ }^{163}$ To Holmes, dissenting, the case was governed by Atherton: if the domicile of one party could grant a divorce, so could the domicile of the other. ${ }^{164}$ In modern terms both White and Holmes

${ }^{168}$ See D. Currie, Suitcase Divorce in the Conflict of Laws: Simons, Rosenstiel and Borax, 34 U. CHI. L. REv. 26, 47-48 (1966).

${ }_{189}$ But cf. Clark v. Barnard, 108 U.S. 436, 447 (1883) (finding the eleventh amendment's facially absolute ban on the exercise of federal judicial power over certain suits against a state "is a personal privilege which [the state] may waive at pleasure").

${ }_{180}$ See Gould v. Gould, 235 N.Y. 14, 138 N.E. 490 (1923) (French divorce of New Yorkers long resident in France under New York law); D. Currie, supra note 160, at 48 \& n.103 (noting existence of statutes dealing with military personnel). The recognition of the foreign divorce in Gould shows that the jurisdictional label affixed in Andrews did not necessarily deprive parties of a convenient forum; since the Court did not hold due process forbade a divorce outside the state of domicile, recognition might still be permitted though not required.

${ }_{161} 201$ U.S. 562 (1906). For a partial list of the copious commentary on this decision, see H. Goodrich \& E. Scoles, supra note 124, at 263 n.53.

162 Justices Brown, Harlan, Brewer, and Holmes dissented. See id. at 606 (Brown, J., dissenting).

${ }^{163}$ Haddock, 201 U.S. at 573-76.

${ }^{164}$ Id. at 629-31 (Holmes, J., dissenting); cf. Beale, Constitutional Protection of De- 
were wrong.

White was wrong because in Andrews the sole state with any interest in the matter was the domicile of both parties, while in Haddock Connecticut had as legitimate a concern with the status of its domiciliary as New York had in that of its own. Andrews forbade one state to meddle in another's affairs; Haddock gave exclusive authority to one state over a matter that was the concern of two.

Holmes was wrong because it was not unfair to require the departing spouse in Atherton to return to her earlier home for litigation; it would have been unfair to drag the left-behind spouse in Haddock into a forum in a state with which she had had no connection. ${ }^{165}$ White's legitimate concern for the choice-of-law problem in Andrews had blinded him to the fact that in Haddock there was a problem with personal jurisdiction; the traditional insistence on personal service within the state had deafened Holmes in Haddock to the critical distinction in terms of fair play. In the modern view White reached the right result for the wrong reason, and his failure to articulate the real concern left his decision vulnerable to

crees for Divorce, 19 HARv. L. REv. 586, 596 (1906) (asserting that the decision "astonished the whole bar of the country"). White dressed his conclusion in metaphysical terms by saying the marital "res" was located at the marital domicile, which was where the parties had lived before the husband left the state. Haddock, 201 U.S. at 576-78. Since the res was fictitious, its invocation could be neither refuted nor supported, and it did not help his case. See id. at 630 (Holmes, J., dissenting).

But for Maynard v. Hill, 125 U.S. 190 (1888), discussed in D. CuRRIE, supra note 3, ch. 11, which had held that marriage was not the kind of transaction protected by the contract clause, White might better have argued that Connecticut had impaired the obligation of the marriage contract contrary to article I, section 10, by applying its own law to dissolve a marriage subject in its inception only to the grounds of divorce specified by New York law. Cf. M'Millan v. M'Neill, 17 U.S. (4 Wheat.) 209 (1819) (contract clause offended by application of state insolvency law to contract governed when made by law of another state), discussed in D. CURRIE, supra note 3 , ch. 5 . An argument could still have been made that it was as unfair to determine the rights of the stay-at-home spouse on the basis of the law of a state with which she had had no connection as to subject her to that state's exercise of judicial power. See Sedler, Judicial Jurisdiction and Choice of Law: The Consequences of Shaffer v. Heitner, 63 Iowa L. REv. 1031, 1033 (1978); Silberman, Shaffer v. Heitner: The End of an Era, 53 N.Y.U. L. REv. 33, 88 (1978) ("To believe that a defendant's contacts with the forum state should be stronger under the due process clause for jurisdictional purposes than for choice of law is to believe that the accused is more concerned with where he will be hanged than whether.").

${ }^{185}$ See D. Currie, supra note 139, at 548-50. Compare McGee v. International Life Ins. Co., 355 U.S. 220 (1957) (allowing judgment to be entered against a nonresident insurance company on a contract that had a substantial connection with the forum state), with Hanson v. Denckla, 357 U.S. 235 (1958) (refusing to permit a judgment against a nonresident trust company whose customer became domiciled in the forum state after the transaction had occurred). 
an attack that should not have succeeded. ${ }^{166}$

In terms of the outcome, White's greatest obstacle was Maynard $v$. Hill, ${ }^{167}$ in which the Court had upheld a divorce granted by a territorial legislature to a husband who had moved there from the marital domicile despite the absence of the wife. Without attempting to argue that personal jurisdiction requirements were inapplicable to legislative divorces, ${ }^{168}$ White distinguished Maynard as having held only that the divorce was valid in the territory where it had been rendered, not that it was entitled to respect elsewhere. ${ }^{168}$

The dissenters effectively pointed out the difficulty of reconciling the conclusion that a judgment valid where rendered was not entitled to full faith and credit with the text or purpose of the clause and its implementing statute. ${ }^{170}$ Haddock itself graphically illustrated the problem: as later Justices were to observe, the result of that decision was that the Haddocks were married in one state and not in another ${ }^{171}$ _clearly an intolerable arrangement in a federal system.

Modern analysis would have enabled the Court to avoid this problem by holding that a divorce entered by a court in a state with which an absent defendant had no contact was entitled to no respect anywhere because it deprived the defendant of liberty or property without due process of law. ${ }^{172}$ At the time of Haddock,

${ }^{188}$ See Williams v. North Carolina, 317 U.S. 287, 296-301 (1942) (overruling Haddock); id. at 316-320 (Jackson, J., dissenting) (complaining that Williams meant that "settled family relationships may be destroyed by a procedure that we would not recognize if the suit were one to collect a grocery bill").

167125 U.S. 190 (1888).

${ }^{168}$ Cf. Chicago, M. \& St. P. Ry. v. Minnesota, 134 U.S. 418 (1890), discussed in D. Currie, supra note 1, at 371-74. In any event, Allgeyer v. Louisiana, 165 U.S. 578 (1897), had already established that due process limited the territorial scope of substantive state legislation. See supra notes 114-17 and accompanying text. If Maynard was still law, it thus seemed to dispose of White's concern that Connecticut was meddling with a marriage whose continuation was none of its business.

${ }^{169}$ Haddock, 201 U.S. at 574-75.

${ }^{170}$ Id. at 626 (Brown, J., dissenting); id. at 632-33 (Holmes, J., dissenting). The statute provided that judicial proceedings "shall have such faith and credit . . . in every court . . . as they have . . . in the courts of the State from which they are . . taken." Act of May 26, 1790, 1 Stat. 122 (codified as amended at 28 U.S.C. $\$ 1738$ (1982)).

172 See Williams v. North Carolina, 317 U.S. 287, 299-300 (1942).

172 See D. Currie, supra note 160 , at 28 . As an original question one might have doubted whether marriage rights were either "liberty" or "property" within the due process clause. See D. Currie, supra note 1, at 375-78 (discussing Allgeyer v. Louisiana, 165 U.S. 578 (1897)). But the Court in holding that the clause protected "liberty of contract" had defined the terms so broadly that the inclusion of marriage should no more have raised eyebrows when Haddock was decided than it did when due process was first applied to a divorce case many years later. See Alton v. Alton, 207 F.2d 667 (3d Cir. 1953). 
however, the distinction between validity at home and respect abroad for decisions not satisfying traditional jurisdictional standards was firmly established; ${ }^{173}$ to have reached the due process question would not only have required confronting Maynard but would also have gone beyond what was necessary to decide the case.

\section{CoNCLusion}

"Oh, but there were Giants on the Court in those days." So Fuller is reported to have said of his early years on the Bench, ${ }^{174}$ and so there were. Within a short time, however, the three tallest gave way to ordinary mortals: Miller, Bradley, and Field were replaced by Brown, Shiras, and McKenna. These sad substitutions set the tone for what was to come; in terms of personnel, the Fuller period was a drab time in the history of the Court.

Matthews, Blatchford, and Lamar also disappeared early, but they were hardly missed. Jackson, Moody, and Lurton served too briefly to make much of an impression. ${ }^{175}$ Of the eleven Justices who did the bulk of the constitutional work during this period, only four have a serious claim to eminence in that field.

The first is Gray, whose erudition was said to have approached Story's, ${ }^{176}$ and who had made a substantial contribution to the work of the Court during the eight years preceding Fuller's appointment. Though he continued to sit for more than half the Fuller era, however, his performance was rather disappointing. $\mathrm{He}$ wrote none of the important economic decisions, nor did he dissent from them. His major constitutional work was in the abstruse fields of full faith and credit and the negative effect of the commerce clause, where he argued for greater state authority and helped rationalize the confused law. His opinions tended to be larded with history, but his use of history was more affected than

17s Professor Beale, supra note 166 , at 594 , indignantly denied there was any such distinction; but the initial state judgment in D'Arcy v. Ketchum, 52 U.S. (11 How.) 165 (1851) (upholding state's refusal to give full faith to New York judgment rendered without service of process on defendant), discussed supra note 91, for example, had been entered in accordance with a statute that the Court did not even suggest was unconstitutional. See Schofield, The Doctrine of Haddock v. Haddock, 1 ILL. L. REv. 219, 225-29 (1906).

174 See W. KrNG, supra note 10 , at 125.

178 Moody was a much-admired lawyer, forced by ill health to retire after only four years but nonetheless described as "one of the ablest Justices of his period." See id. at 308$09,316-17$.

170 See, e.g., id. at 132-33. 
effective. ${ }^{177}$ There was no need to explore all Western civilization to prove that the fourteenth amendment meant what it said about the children of aliens born in the United States, ${ }^{178}$ for example, and history gave conflicting answers to the scope of the penal exception to recognition of judgments, which he resolved in Huntington $v$. Attrill by mere assertion. ${ }^{179}$ Despite his promise, in constitutional cases Gray was neither an important voice on the Fuller Court nor distinguished by the quality of his opinions.

The other significant holdover from the Waite days was Harlan, who continued to sit with great vigor throughout the time Fuller was Chief Justice. He wrote over a hundred constitutional opinions during this period, substantially more than any other Justice. He also differed with his brethren far more than anyone else, and he found time to write about fifty dissenting opinions in constitutional cases-three times as many as any of his colleagues.

As foretold by his earlier record, Harlan's work was most noticeably marked by his strong support for civil rights and for the police power. In a series of impassioned dissents, he argued for racial equality, for the incorporation of the Bill of Rights in the fourteenth amendment, and for the application of constitutional provisions to the territories. He wrote for the Court to uphold several important economic measures and dissented from the invalidation of several others. While alert to protect interstate activities from practical as well as facial discrimination, he was perhaps the leading exponent of the emerging principle that reasonable policepower measures should be upheld despite their effects on commerce. Yet for all this he was no opponent of substantive due process as such; it may come as a surprise that he was the author of the famous opinions invalidating unreasonable rail rates and the ban on contracts not to join unions.

Even a brief recitation of Harlan's accomplishments reveals him as a figure of considerable importance in the Court's history, and the country has since come around to many of the views he

177 " [I] $\mathrm{t}$ is this very adherence to the common law and exhaustive historical research which, in the writer's view, deprived Gray of his rightful place in the history of the Supreme Court . . ." Smith, Mr. Justice Horace Gray of the United States Supreme Court, 6 S.D.L. REv. 220, 246 (1961).

${ }^{178}$ See D. Currie, supra note 1, at $338 \mathrm{n} .87$ (discussing United States v. Wong Kim Ark, 169 U.S. 649 (1898)).

179 See supra notes 86-97 and accompanying text. "Holmes used to say of Gray that the premise of his opinion and the conclusion stood forth like precipices, with a roaring torrent of precedents between, but he never quite understood how Gray got across . . .." Francis Bidde, Mr. Justice Holmes 103 (1942). 
expressed in often solitary dissents. ${ }^{180}$ In several important opinions, moreover-such as the dissents in Lochner, ${ }^{181}$ E.C. Knight, ${ }^{182}$ and Plessy $v$. Ferguson ${ }^{183}$ - he put forth persuasive arguments in support of his position. He lacked the incisiveness of Miller or Taney, the learning of Bradley or Story, the magisterial style of Curtis or Marshall, the imagination and theoretical strength of Field. ${ }^{184}$ Nevertheless, by any criterion he was one of the standouts of the Fuller period.

The third Justice of note was White, who in sixteen years with Fuller richly earned his unprecedented promotion to succeed the latter as Chief Justice. Though he did not write for the Court in the great economic controversies of the day, he captured attention by the power and originality of his theories in three fields outside the mainstream. It was White who first explained the limits of the nondelegation doctrine in realistic modern terms, who fought tenaciously for an interpretation of the full faith and credit clause that would allow states to regulate their own affairs, and who advocated the powerful incorporation thesis ultimately adopted to govern the status of territories. White's most conspicuous failing was in Mankichi, where he neglected to explain why the argument he had expressly employed only as an interpretation of a clause limited to "the United States" applied to jury-trial provisions containing no such limitation. ${ }^{185}$ But he was a major intellectual force on the Court at a time when they were in short supply.

We come at last to Holmes. From the day he arrived, the man with the marvelous mustache displayed dazzling skills that left his more pedestrian colleagues in the shade. In terms of sheer productivity he was prodigious. In eight years he cranked out nearly as many constitutional opinions as the Chief Justice wrote in over twenty, far surpassing even Harlan in constitutional opinions per year. He turned them out with remarkable alacrity; cases in which Holmes wrote were not infrequently decided within two weeks af-

${ }^{180}$ See Frank Latham, The Great Dissenter passim (1970); Watt \& Orlikoff, The Coming Vindication of Mr. Justice Harlan, 44 ILL. L. Rev. 13 (1949); White, John Marshall Harlan I: The Precursor, 19 AM. J. LEg. Hist. 1 (1975). For a laudatory assessment at the time of his death, see Brown, The Dissenting Opinions of Mr. Justice Harlan, 46 AM. L. REv. 321 (1912).

${ }_{181}$ Lochner v. New York, 198 U.S. 45, 65 (1905) (Harlan, J., dissenting).

${ }_{182}$ United States v. E.C. Knight Co., 156 U.S. 1, 18 (1895) (Harlan, J., dissenting).

${ }^{183} 163$ U.S. 537, 552 (1896) (Harlan, J., dissenting), discussed in D. CuRRIE, supra note 3 , ch. 11 .

184 Holmes once wrote that Harlan's mind was "a powerful vise the jaws of which couldn't be got nearer than two inches to each other." W. KING, supra note 10, at 131 .

${ }^{185}$ See supra notes $72-81$ and accompanying text. 
ter argument. ${ }^{186}$ And his style! His opinions are a breath of fresh air. Gray, Harlan, and White could make good ideas uninteresting; Holmes made the dullest case a literary adventure.

Yet, for all their stylistic appeal, the constitutional opinions of Holmes's first years are substantively not very satisfying. He was adept enough in putting forth interesting ideas, such as the current-of-commerce theory justifying federal regulation of stockyard sales, but he tended to advance them essentially as unsupported conclusions. His treatment of the serious freedom of expression issues in Patterson $v$. Colorado ${ }^{187}$ was indifferent in the extreme. ${ }^{188}$ His most celebrated opinion of the time illustrates his inclination to substitute epigrams for analysis: instead of taking Lochner as the opportunity to show what the due process clause was all about, Holmes contented himself with the smug assertion that the clause did not "enact Mr. Herbert Spencer's Social Statics." 189

Like Harlan, Holmes was important because history has embraced his frequent dissenting views. Like no one before him, he was a master of the well-turned phrase. Like Miller, however, he did not always take the trouble to justify his clever conclusions; ${ }^{190}$ and he wrote few of the major decisions of the Court while Fuller was Chief Justice.

Fuller, who at the beginning kept for himself such monumental opinions as those on the sugar trust and the income tax, later left the big cases to others to a degree quite foreign to the practice of his four immediate predecessors. ${ }^{191} \mathrm{He}$ stayed away from the great due process cases, though he joined them; in the politically significant insular cases he found himself in dissent. Indeed, though Fuller wrote dissenting opinions only in major cases-he was recorded as dissenting at least fifty times in constitutional

${ }^{186}$ See W. KING, supra note 10, at 290-91 (noting that Holmes often asked for more work and quoting Holmes's observation that "[a] case doesn't generally take more than two days if it does that.").

${ }_{187} 205$ U.S. 454 (1907), discussed in D. Currie, supra note 1, at 374 n.301.

${ }^{183}$ Cf. Rogat, Mr. Justice Holmes: A Dissenting Opinion (pt. 2), 15 STAN. L. REv. 254, 308 (1963) (arguing on the basis of decisions respecting aliens and race that "the accepted image of Holmes as uniquely libertarian owes more to the fantasies unloosed by the attractiveness of his personality than to the realities of his career").

${ }^{189}$ Lochner v. New York, 198 U.S. 45, 74 (1905) (Holmes, J., dissenting).

190 See Rogat, Mr. Justice Holmes: A Dissenting Opinion (pt. 1), 15 STAN. L. REv. 3, 9 (1962); White, The Integrity of Holmes' Jurisprudence, 10 HorsTRA L. REv. 633, 664, 671 (1982) (describing Holmes as "a judge whose principal interest seems to have been in having cases decided, written up, and disposed of" and tracing this attitude to a conviction that judging was largely a matter of arbitrary preferences that could not be satisfactorily explained).

${ }^{191}$ See W. KrNG, supra note 10 , at 332-33. 
matters-he was in far less control of the outcome than either Taney or Waite had been, not to mention Marshall. Moreover, the quality of his opinions was not high. Leisy ${ }^{\mathbf{1 0 2}}$ was a string of unfocused quotations, E.C. Knight ${ }^{193}$ distorted the controversy, Pollock $k^{194}$ was internally contradictory and neglected available arguments. The contrast between Fuller's conclusions that the sugar trust did not restrain commerce and that the Danbury hat boycott did suggests that he may not have been guided exclusively by neutral legal principles. ${ }^{195}$

Brewer and Peckham were in the forefront of the Court's assault on social legislation. Brewer continued to argue that rate regulation was unconstitutional, took the lead in the few decisions striking down measures on equal protection grounds, and dissented from several decisions rejecting due process objections to state regulatory provisions such as the limitation of miners' hours. ${ }^{196}$ Peckham was the Court's chief spokesman for the new liberty of contract and dissented even more frequently from decisions upholding state or federal regulation. Peckham was not an effective advocate: Allgeyer ${ }^{197}$ and Lochner ${ }^{198}$ were bare conclusions, Ex parte Young ${ }^{199}$ butchered the law of sovereign immunity, and he almost never bothered to explain his dissenting votes. Brewer was not so noticeably weak, and his commitment to economic rights was coupled with a conspicuous respect for civil rights as well, most prominently in cases respecting aliens. But in Debs ${ }^{200}$ he seemed oblivious to the distinction between congressional and judicial power, and his opinions in general do not make much of an impression.

Four Justices remain: Brown, Shiras, McKenna, and Day. Brown was a relatively important member of the Court, best known today for his callous opinion in Plessy $v$. Ferguson, ${ }^{201}$ con-

102 Leisy v. Hardin, 135 U.S. 100 (1890).

${ }^{103}$ United States v. E.C. Knight Co., 156 U.S. 1 (1895).

104 Pollock v. Farmers' Loan \& Trust Co., 157 U.S. 429, modified on reh'g, 158 U.S. 601 (1895).

${ }^{195}$ Fuller's skills as presiding Justice, however, were widely admired. Miller and Holmes, for example, both of whom served with a number of Chief Justices, were said to have regarded Fuller as the best presiding judge they had encountered. See W. KING, supra note 10 , at $127,290,333-34$.

${ }^{106}$ For a rather sympathetic modern assessment, see Garner, Justice Brewer and Substantive Due Process: A Conservative Court Revisited, 18 VAND. L. REv. 615 (1965).

197 Allgeyer v. Louisiana, 165 U.S. 578 (1897).

${ }^{198}$ Lochner v. New York, 198 U.S. 45 (1905).

199209 U.S. 123 (1908).

${ }^{200}$ In re Debs, 158 U.S. 564 (1895).

201163 U.S. 537 (1896). 
structive in the development of commerce-clause jurisprudence, and notable for his extreme position that the Constitution applied to none of the territories. ${ }^{202}$ Shiras attracted little attention in nearly a dozen years, writing nothing of interest for the Court but providing a few intelligent dissents. Day sat nearly as long as Holmes and left virtually no trace. McKenna, very likely the most inept writer of them all, ${ }^{203}$ managed an uncharacteristically effective dissent on the commerce clause issue in the yellow-dog case.

In sum, the Fuller period was a time of important decisions; but it was not on the whole a strong period in the Court's history.

${ }_{202}$ See supra notes 46-56 and accompanying text. For a description and criticism of Brown's work as a whole, see Glennon, Justice Henry Billings Brown: Values in Tension, 44 U. CoLo. L. Rev. 553 (1973).

${ }^{203}$ McKenna's appointment prompted two federal trial judges to take the unusual step of writing letters lamenting his unfitness for the post, as evidenced by his performance as a circuit judge. See W. KING, supra note 10, at 228-30 (adding that McKenna's colleagues "always felt in him some judicial inadequacy" and that "Fuller took care to assign to him the simpler cases"). 